\section{Debating Self, Identity, and Culture in Anthropology'}

\section{by Martin Sökefeld}

This paper explores relations between "identity" and "self"—concepts that tend to be approached separately in anthropological discourse. In the conceptualization of the self, the "Western" self, characterized as autonomous and egocentric, is generally taken as a point of departure. Non-Western (concepts of) selvesthe selves of the people anthropology traditionally studies-are defined by the negation of these qualities. Similar to anthropological conceptualizations of identity, this understanding of nonWestern selves points exclusively to elements shared with others and not to individual features. Consequently, anthropological discourse diverts attention from actual individuals and selves. A different approach is exemplified by a case from northern Pakistan in a social setting characterized by a plurality of contradictory identities. It is argued that an analysis of how a particular individual acts in situations involving contradictory identities requires a concept of a self as it emerges from the actions of individuals that is capable managing the respectively shared identities. Besides any culture-specific attributes, this self is endowed with reflexivity and agency. This concept of self is a necessary supplement to the concept of culture in anthropology and should be regarded as a human universal.

MARTIN SÖKEFELD teaches at the Institute of Social Anthropology of the University of Hamburg (his address: Kamerstücken 28, 22589 Hamburg, Germany [martin.soekefeld@joice.net]). Born in I964, he received his M.A. from the University of Cologne in I 990 and his Ph.D. from the University of Tübingen in I997. He has done fieldwork in Gilgit, Pakistan (I99I-92, I992-93), and has published Ein Labyrinth von Identitäten in Nordpakistan: Zwischen Landbesitz, Religion und Kaschmir-Konflikt (Köln: Köppe, I 997), " 'The People Who Really Belong to Gilgit': Theoretical and Ethnographic Perspectives on Identity and Conflict," in Transformation of Social and Economic Relationships in Northern Pakistan, edited by Irmtraud Stellrecht and Hans-Georg Bohle (Köln: Köppe, I998), and "On the Concept 'Ethnic Group,' " in Karakorum-Hindukush-Himalaya: Dynamics of Change, edited by Irmtraud Stellrecht (Köln: Köppe, in press). The present paper was submitted I 2 VII 98 and accepted I4 X 98; the final version reached the Editor's office $23 \times 98$.

I. I would like to thank Katrin Gratz, Beatrix Hauser, and Georg Stöber as well as the anonymous referees for critically reading an earlier version of the paper. The paper was much improved by their suggestions. For many discussions of the topic I am grateful to Beate Reinhold. The text is an outcome of reflection about field research in Northern Pakistan which was generously funded by the Deutsche Forschungsgemeinschaft.
The concept "identity" has undergone a paradigmatic shift in recent decades. Originally, its meaning was "sameness," and in psychology this sameness meant "selfsameness." Identity was understood as a disposition of basic personality features acquired mostly during childhood and, once integrated, more or less fixed. This identity made a human being a person and an acting individual. Inconsistency of personality-that is, nonsameness of the self, nonidentity-was regarded as disturbance or even psychic illness. In social anthropology, the concept "identity" was used mostly in the context of "ethnic identity." Here it pointed not simply to selfsameness but to the sameness of the self with others, that is, to a consciousness of sharing certain characteristics (a language, a culture, etc.) within a group. This consciousness made up a group's identity. These understandings were complementary rather than contradictory and fitted well together, as the group to which a person belonged constituted an important part of the social environment in which and through which personal identity was formed. Erik H. Erikson combined the two: "The term 'identity' expresses such a mutual relation in that it connotes both a persistent sameness within oneself (selfsameness) and a persistent sharing of some kind of essential characteristics with others" (Erikson I980:I09). Common to the usage of the term "identity" in the two disciplines was that identity was basically one.

In the European history of ideas, the notion of the sameness of the self had had foundational qualities since Descartes's Meditationes. The cognizing self (ego, I), certain of its existence through its own acts of cognition, became the warranty against an ambiguous and deceptive world of things. This warranty was valid only on the condition that ego remained the same, that is, identical. The self thus became subject in the dual sense of being subjected to the conditions of the world and, simultaneously, being the agent of knowing and doing in that world. The belief in this subject became the a priori for the possibility of knowing the world.

The metanarrative of the identical subject was finally destroyed by poststructuralist deconstruction. Michel Foucault analyzed the subject not as the source and foundation of knowledge but as itself a product or effect of networks of power and discourse (1979:35; I980:98). In contemporary texts on identity, the concept seems not to exist in the singular. Whereas it was once defined by sameness and unity, both qualities have given way to difference and plurality. Psychology has turned its attention to multiple identities (Gergen I994, Melucci I997, Rosenberg I997)—which, according to the word's conventional meaning, is a contradiction in terms. The contemporary self is depicted as fragmented (Jameson I984), essentially fluid and many-sided, as in Lifton's "protean self" (I993), or populated by multiplicities, as in Gergen's "saturated self" (I99I). In the social and cultural sciences, what was once called "identity" in the sense of social, shared sameness is today often dis- 
cussed with reference to difference. ${ }^{2}$ Difference points to the contrastive aspect of identities and thereby emphasizes the implicit condition of plurality. There can be identity only if there is more than one identity, and in this sense difference constitutes and precedes identity. I will argue that the emphasis on difference calls into question anthropologists' conventional assumption of shared identity and demands attention to a personal or individual identity that is here called the self. Discourses about the self and about identity in anthropology are almost entirely distinct; I am calling for the establishment of a closer connection between them. This connection is in my view inevitable because increased attention to the social and cultural contexts of plural identities leads to a reworking of both concepts.

The significance of the self is greatly underestimated in anthropology. Two approaches to the subject can be distinguished. The first implicitly maintains that anthropology's subjects have an identity (shared with others, derived from a culture) instead of a self. The second analyzes the selves of these subjects by contrasting them with a paradigmatic conceptualization of the "Western self" (that is, the still mostly Western anthropologist's own self), and because it denies the paradigmatic characteristics of the Western self to anthropology's non-Western subjects it actually denies them a self. Anthropology's treatment of the self of its subjects is an effective strategy of othering-positing a basic difference between anthropologists and those they study.

To counter both approaches I will proceed as follows: After introducing my thesis of anthropology's denial of others' selves, I will present a case of plural and conflicting identities in a town in the mountains of northern Pakistan. From this case I will draw the conclusion that it is impossible to conceive of the actions of individuals embracing a plurality of identities without referring to a self. After exploring meanings of and relations between self and identity as they can be interpreted from my material, I will discuss the relations between anthropological understandings of culture and self.

\section{Anthropology's Denial of Others' Selves}

Anthropologists write easily about the identity of those they study in the sense of something shared with others, but they have much more difficulty in attributing a self to the people they are writing about. The attribution of a nonself to these others is expressed in debate about intercultural variability of (concepts of) the self, in which the Western self is opposed to the self of the non-West (see Spiro I993). In this debate the Western self is represented as an instance of the individual's providing it with boundedness, relative autonomy and independence, reflexivity, and the ability to pursue its

2. On a related change in discourse from identity to difference in feminist studies, see Crosby (1992). own goals. Clifford Geertz has characterized the Western concept of the self as "peculiar" in that it is "a bounded, unique, more or less integrated motivational and cognitive universe, a dynamic center of awareness, emotion, judgement and action organized into a distinctive whole and set contrastively against other such wholes and against its social and natural background" (Geertz I984:I26). This self fits neatly with the subject of Descartes's Cogito.

Anthropological characterizations of "the other" are often inversions of European self-images (Fardon I990: 6). This certainly applies to understandings of others' selves. In the conceptualization of non-Western selves, the Western self ${ }^{3}$ was taken as the starting point and the non-Western self was accordingly characterized as its opposite: unbounded, not integrated, dependent, unable to set itself reflexively apart from others, unable to distinguish between the individual and a role or status that individual occupies, unable to pursue its own goals independently of the goals of a group or community. Effectively, this characterization involved the negation of all the definitional qualities of the self, that is, of those that point to the differentiation of the self from others. We can conclude, then, that by being denied a Western self, anthropology's others were denied a self at all. Many or even most anthropologists would hesitate to subscribe to this rather polemical proposition, but it simply carries the logic of this anthropological approach to its logical conclusion. A well-known instance of this perspective is Geertz's (1973) description of the self in Bali. According to his analysis, the Balinese person is extremely concerned not to present anything individual (distinguishing him or her from others) in social life but to enact exclusively a culturally prescribed role or mask. Similarly, in the anthropology of South Asia there is an ongoing debate about whether the people of the subcontinent are endowed with anything comparable to a self (in the paradigmatic Western mode), that is, whether they can be spoken of as individuals. ${ }^{4}$

3. The concept of the Western self requires a discussion in itself which cannot be undertaken here for want of space. The understanding of the Western self as autonomous and integrated is mostly derived from (selected [see Murray i 993]) Western written philosophical traditions and not from analyses of experiences of people in the West. Some recent studies suggest that there are different kinds of Western selves and that the differences between Western and non-Western selves may be much less than is usually assumed (e.g., Holland and Kipnis I994, Ouroussoff I993, Stephenson I989). It seems, then, that the concept of the Western self that pervades anthropological analyses of non-Western selves is the result of a particular kind of Occidentalism (Carrier I992, I996a). 4. According to Dumont (I965, I970, I980), from the South Asian cultural perspective individuals are always elements of larger social units in which all value is vested. Marriott takes the contrasting stance that there are no individuals but only "dividuals" in India, because human beings are only temporary and constantly transformed compositions of elementary coded substance (I976, I989; Marriott and Inden I977). Both positions have been heavily criticized from different perspectives (see Mines I988, I994; Morris I978). Mines (1994), exploring both public and private aspects of individuality in Tamil Nadu, shows convincingly that individuality and personality are indispensable to social life in South India, although they are conceived differently than in Western societies. The same conclusion is reached by McHugh (I989) in her analysis 
In spite of the psychological definition of identity as selfsameness, this denial of a self does not amount to a denial that, for instance, Indians have an identity in the anthropological sense. Dumont and Marriott, who argue in their own ways against the individuality of people in India, would hardly deny that Indians have identities. In this understanding, then, Indians have an identity instead of a self. Contrary to the meaning of "identity" in psychological usage, identity here refers not to an idiosyncrasy of the individual-a bundle of features that distinguish her or him from others-but to identity with others, with one's cultural/social group. This idea pervades Lévy-Bruhl's conceptualization of the "primitive soul." ${ }^{5}$ We have to keep in mind that the people who are ascribed such an identity are always others and the objects of anthropological discourse. Anthropologists generally do not apply this understanding of identity to themselves and members of their own society. People who have only such an identity are not autonomous, independent, and pursuing their own goals; they are dependent on their cultural/ social group and behave according to the prescriptions and interests of that group. ${ }^{6}$ Cultural and social determinism lurks behind this conceptualization of nonWestern selves.

In anthropological discourse, the question of identity is almost completely detached from the problem of the self. In the vast body of literature about ethnic identity the self is rarely mentioned, and in writings about the self a relation between the self and identities is sometimes noted but remains unexplored (e.g., Morris I994: I). However, if we look at analyses of non-Western concepts of the self, it cannot go unnoticed that these concepts of the self (as represented by anthropologists) are modeled precisely on the anthropological understanding of identity: they are sociocentric (Mageo I995, Read I967, Shweder and Bourne 1984), just as identities are social and shared.

In recent years, committed arguments have been made for the self as a basic human condition. The outstanding example here is Anthony Cohen (I994), and it is significant that his book on self-consciousness is subtitled "an alternative anthropology of identity" (my italics). Cohen argues that the disregard for others' selves in anthropological accounts results in distorting fictions, denying self-consciousness to the people anthropologists study. Most frequently this disregard is expressed in a premature subsumption of individuals under the groups to which they belong. He maintains that to attend to the self in anthropological inquiry is

of individuality among the Gurung of Nepal. However, there are Indian writers who argue that there are no bounded individuals in India (e.g., Vaidyanathan I989).

5. According to Lévy-Bruhl, the members of "primitive" groups possess not an "individual individuality" but rather a "shared individuality" and a "quasi-identity" to the extent that they are almost interchangeable (Lévy-Bruhl I963[I927]:99).

6. This understanding of non-Western "selves" is carried to extremes by much fiction writing, where the non-European is simply an "atom in a vast collectivity" (Said I995[I978]:252). not to indulge in individualism but to problematize what is otherwise taken for granted: the relationship between the individual and the social. How does the self relate to groups, to society, or, in the present context, to shared identities? These questions have to be asked, Cohen argues, not "to fetishize the self but, rather, to illuminate society" (p. 22). Cohen was followed by Rapport (I997), whose call for attention to self and individuality is even more radical. For him such an approach is an ontological necessity, because "it is in individuality that the roots of the social and cultural lie" (p. 2). Cohen's and Rapport's arguments still seem to be in the minority. I intend to support this approach by exploring the relationship between the self and plural identities.

What if the people anthropologists study cannot be categorized by shared identities? What if their identity is not one but, as in a plural society, a collection of differences setting them off from varying groups of others? if each individual is characterized by a specific pattern of differences from and commonalities with certain others? if what is shared with some conflicts with what is shared with others? The implicit parallelism of self and identity in anthropology as something essentially shared does not fit into the conceptualization of plural societies. My conclusion from the following case will be that there can be no identities without selves. This case from northern Pakistan is not about a cultural concept of the self. It is about whether we can discern something besides the changing identities of the "empirical agent" (Dumont's term)-that is, whether we have to conceive of an acting self in addition to its identities.

My field research in the multi-"ethnic" town of Gilgit in the Northern Areas of Pakistan, was on "ethnicity." Educated anthropologically in the tradition of Durkheimian and social anthropological approaches, I was determined to focus on groups rather than on acting individuals or selves. The episode related here forced me to acknowledge the importance of acting individuals in a study of "ethnic" identity. It is an example of the struggle to act and to present oneself as a consistent self in a situation of plural and contradicting identities related to intense social conflict.

\section{Conflicting Identities and a Self in Gilgit}

Gilgit, a town of about 50,000 inhabitants, is the administrative and commercial center of the Northern Areas of Pakistan. The population of the area is highly differentiated by a number of dimensions of identity. Migration to the urban area has made the composition of the population very complex. Some important dimensions of difference (i.e., identity) are religious affiliation, language, regional belonging, $q \bar{o} m,{ }^{7}$ clan, and kinship

7. The meaning of $q \bar{o} m$ is quite broad and ranges from kinshipbased groups to the political nation (Sökefeld n.d.a). In the present context it can be translated as "quasi-kinship group." 
(Sökefeld I997a). In the present context two of these, religion and kinship, will play the major part.

For two and a half decades the town's population has been split by a militant conflict between Shiites and Sunnis, with periodically erupting tensions between members of the two groups. From I975 onward, weapons were used in these encounters, which regularly resulted in losses of life. When I was staying in Gilgit between I99I and I993, the population was effectively polarized by the experience of almost 20 years of violence. ${ }^{8}$ Intermarriage between Shiites and Sunnis had ceased when the conflict began. Kinship relations across the religious boundary, which before had been very common, were being neglected if not altogether denied. A considerable relocation of settlement in Gilgit and the surrounding villages had resulted in a number of "pure" Shiite or Sunni neighborhoods where members of the two sects had earlier lived together. Some parts of the bazaar could now be identified as being either Shiite or Sunni. Commensality between Shiites and Sunnis had ceased almost totally. This applied especially to meals including meat, because the shari' $a$, the Islamic law, prescribed that only meat of animals slaughtered by Muslims was permitted. The refusal to eat meat provided by the other sect amounted implicitly to the judgment that the others were not really Muslims but infidels (kuffär). Separation always reached its highest pitch during and just after a period of tension.

The polarization of Shiites and Sunnis found its strongest expression in the mutual accusation that the others were kuffār (singular kāfir). Kuffär are nonbelievers. They are impure. Muslims can have no real companionship with them. It is impossible to share a meal with them, let alone family ties. By no means all Shiites called Sunnis kuffär and vice versa; to accuse someone of being a kāfir was so strong and dishonoring a reproach that most people hesitated to voice it publicly, and many people were certainly not of the opinion that the others were indeed kuffär. Still, the reproach was sometimes made in public, and graffiti expressing it could sometimes be seen on the walls of the town. These incidents always caused intense disturbance and resentment among those being called kuffär.

Although the difference between Shiites and Sunnis had become very sharp, it was not devoid of ambiguity arising from the fact that each person embraced identities derived not only from religious affiliation but also

8. Kuper's concept of polarization fits the scene in Gilgit well: "Polarisation is conceived here as involving mutually hostile action. .. I reserve the term for an intensification of conflict by aggressive action and reaction. Polarisation then is a process of increasing aggregation of the members of the society into exclusive and mutually hostile groups, entailing the elimination of the middle ground and of mediating relationships. Episodes of conflict accumulate. There are corresponding ideologies ..., presenting simplified conceptions of the society as already polarised into two antagonistic groups with incompatible and irreconcilable interests, rendering inevitable the resort to violence" (Kuper 1977:I28). from others, for example, to clans, localities, or language communities. In spite of the religious polarization which had pushed the religious identity to the fore, other identities continued to be relevant. The religious identity might conflict with other identities of the same person, and this meant conflict between opposed values and objectives. At times, the value of conforming and being loyal to one's sect proved irreconcilable with the value of keeping one's family together and caring for one's relatives because a relative was regarded as käfir. The self, then, embraced conflicting identities.

Still, people tried to reconcile these values. They pursued various and at times contradictory objectives, sometimes simultaneously. How did they develop a sense of a continuous and consistent self in this context? Or did they do without one? I want to explore these questions in an episode of fieldwork which I experienced with Ali Hassan, ${ }^{9}$ the man who taught me much of what I learned about culture and society in Gilgit.

\section{Ali Hassan}

Ali Hassan was a Shiite, a member of the Yeśkun qōm and within it of the Catōrē clan. He was a respected elder of his qōm and of the town as a whole. He possessed considerable agricultural land both in the part of Gilgit where he lived and in a more distant place on the edge of town. This peripheral area was cultivated by a tenant, since Ali Hassan had suffered a heart attack in I992. The tenant belonged to the Gujur ${ }^{10} q \bar{o} m$ and was a Sunni. Ali Hassan also owned three houses and nine shops which he rented out, and more shops were under construction.

Ali Hassan had been his father's first son after eight marriages, and of course his father had feared losing him. Therefore he had been given as a "milk son" to a Sunni Gujur family from a neighboring valley, where he had stayed for three years. At the age of I 5 he had married a girl of another Yeśkun clan. When I met him, he was in his sixties and still versatile and innovative. Being very generous, he helped his relatives and others out with firewood, produce from his lands, and assistance in dealing with the authorities. His conception of "relatives" was very inclusive. If it suited his purposes, he could conceive of a relation with almost anyone. $\mathrm{He}$ spent a considerable part of his life attending to relationships.

Being a very pious Shiite, Ali Hassan visited the main mosque every day to offer the midday prayer. He was completely convinced that his sect was right in the religious conflict. He always reiterated that it was not Shiites who had begun the conflict and that they were very much against sectarian violence. In spite of his loyalty

9. Personal names are pseudonyms. Io. The Gujur mainly practice animal husbandry and menial labor, and their prestige is quite low. 
to the Shiite cause, he maintained a quite independent stance. Conscious of many contradictions between riwāj (local custom) and sharī'a, Ali Hassan preferred many norms of the former, for example, those regulating landed property and inheritance. Only if forced by an explicit judgment would he have complied with the norms of sharì'a in these matters.

Although in his opinion the conflict between Shiites and Sunnis was the Sunnis' fault, he did not condemn them indiscriminately. The guilty parties, those who slandered Shiites as kuffär, were the "new" SunnisTablīghī, Wahabī, and Deobandī. ${ }^{11}$ In his estimation, the real, righteous, traditional Sunnis, whom he termed Brelwi or Hanafīi, ${ }^{12}$ disapproved of the conflict as much as the Shiites. Further, he distinguished Sunnis according to kinship or qōm membership. There were his "own," xāndānin'13 Sunnis-those with whom he shared qōm membership or kinship or who were at least proper people of Gilgit-and there were other, "foreign" ones-nonrelatives, people of other qōm, and especially immigrants such as Pashtūn and Kashmīrī. The separation established by differential religious affiliation could in his view be at least partially erased by some other relation. All the relations established by religion, descent, kinship, etc., were possible bases of community. For example, Ali Hassan told me that he rented his shops and houses only to Shiites and Ismailis because both basically belonged to one religion and no dispute would arise with them. However, as we have seen, one of his tenants was a Sunni-Gujur and a relative of his "milk" family. On another occasion Ali Hassan told me that Pashtūn were always pressuring him to rent them a shop, but he resisted because they were foreign and not xāndānī, and he emphasized that he was prepared to rent a shop to xāndānī Sunnis.

While we were talking about the shops, one of Ali Hassan's affines who was present, another Yeśkun, told me that many Sunnis belonged to their qōm and that a number of his sisters and female cousins were married to Sunnis. Then he added, "But for us Shiites, Yeśkun religion is more important than $q \bar{o} m$. This is very differ-

I I. Tablīghī are the followers of the Tablīghī Jamāt, a lay missionary movement founded in the I920s in northern India that aims to bring Muslims back to the right path, that is, to the prescribed observances such as daily prayer (Ahmad I99I). Deobandī are the followers of the famous North Indian Islamic seminary at Deoband, which propagates an orthodox version of Sunni Islam (Metcalf I 989). Most Sunni ulema in the present-day Northern Area belong to the Deoband school. Wahabi are the followers of Saudi Arabian Wahabiyya.

I2. Brēlwi are the followers of the school of Bareilli, the rival of the seminary of Deoband, which propagates a kind of folk Islam holding Sufism and local saints in high esteem (Metcalf I989). Hanafi are followers of the law school ( fiqh) of Abu Hanifa. Here Ali Hassan's categorization is incorrect; all the types of Sunnis mentioned are Hanafī. Shiites, in contrast, are Jafrī, followers of the fiqh of Imam Ja'far as-Sādiq.

I3. Xāndānī is derived from xāndān, "family," but it means not only belonging to a kinship group but also sharing basic traditions and value orientations. For a detailed analysis, see Sökefeld (I997a, I998). ent among Șinn. For them, a Șinn is in the first place Șinn, not Shiite or Sunni. This is very good; it should be like that also among Yeśkun!" 14

At the same time, Ali Hassan and other respected Yeśkun from Gilgit and other places were endeavoring to organize a meeting of their $q \bar{o} m$ in order to overcome the religious cleavage within their group and to gain strength for the Yeśkun in confronting other qōm, especially the Șinn. Sunni Yeśkun were part of this effort. I was often told by Yeśkun that it was only their own $q \bar{o} m$ that was divided and thus weakened by religious conflict. Some Yeśkun even attributed the whole conflict to a conspiracy of Șin against Yeśkun. For Ali Hassan, the benefit of an assembly of Yeśkun was self-evident. It was a value in itself to promote the solidarity of one's qōm. He had told me several times that he was Shiite in the first place and that religion was most important for him, but in the situation described here this was obviously not the case. The aim of the whole endeavor was precisely to subordinate religion to qōm.

Do then these contradictory basic identities-qōm, kinship, and religion-create separate "compartments" of the person? Do they prevent the development of a sense of a consistent and continuous self? Not quite, as we shall learn by accompanying Ali Hassan to the wedding of one of his relatives and listening to his reflections on that visit.

\section{An Uneasy Visit at a Wedding}

One of Ali Hassan's elder sisters had married into a respectable Sunni Yeśkun family at Napura, an old village on the western edge of Gilgit. Years ago this sister had died. Her son Malik Amman was of about the same age as Ali Hassan. Ali Hassan was quite concerned to be on good terms with these Sunni relatives, and I had accompanied him on visits to them several times. In January I993 Malik Amman's granddaughter was going to marry a man from the Punjab. Ali Hassan did not approve of this marriage, but he invited me to accompany him to the wedding. He told me, "I am very angry that she is to marry a Panjābī, but Malik Amman did not ask me. There are plenty of suitable boys in Gilgit!"

The marriage was to take place on a Friday. When I arrived at Ali Hassan's house, he told me that his wife's cousin Sher Khan would come with us. He had formerly been the general secretary of the Shiite community association in Gilgit but, after receiving a personal threat in the religious conflict, had resigned from that office and left. He had returned to Gilgit only a few days before. We went to his place and met him with his son. Because Sher Khan left his house only under the protection of arms, both his son and Ali Hassan's son, who accompanied us, carried Kalashnikovs.

I4. Șin is the other important indigenous $q \bar{o} m$ of Gilgit. Rivalry between Șin and Yeśkun is at times quite strong (see Sökefeld I994). 
It was still morning when we arrived at the home of Malik Amman. We were welcomed very cordially by a number of family members and led into the house. Malik Amman was sitting there with his younger brother Sadiq. After the customary exchange of compliments, he told us that the marriage ceremony would not take place until afternoon. Sher Khan remarked at once that he was unable to stay so long because he had to attend a meeting. Sadiq and Malik Amman urgently attempted to persuade him to stay at least until lunch, but Sher Khan showed no inclination to change his mind. While the exchange between them was going on, we were served sweet tea and dried fruit. After a very short time Sher Khan told us that he had to leave. Again Sadiq insistently begged him to stay without success. Before we got up, Sadiq said a prayer in which he invoked the ahl-e bayt (the family of the Prophet, including his son-in-law Ali). This invocation is a Shiite practice of which "orthodox" (i.e., Wahabī or Tablīghī) Sunnis are very critical. From their perspective, invoking humans in prayer places them close to God and violates the fundamental dogma of monotheism. Immediately after the prayer, we said good-bye and left the house. One of Malik Amman's sons followed us to the jeep, continually pleading with us to stay. Finally, he exclaimed with disappointment in his voice, "Are we contractors of a religion or are we relatives?" But we got into the jeep, left, and returned to the center of town.

The next day I asked Ali Hassan what kind of Sunni Malik Amman was, and he responded, "He is Hanafī. But his brother Sadiq is Tablīghī and strict Wahabī!" Because I had been discussing commensality with other informants, I then asked him, "Is it true that Shiites never eat meat provided by Sunnis?"

Ali Hassan: Yes, they do not share meals in our houses, and therefore we do not eat in their houses.

$I$ : Was this the reason that we left yesterday before the meal was served?

Ali Hassan: No, we left because the marriage was to take place only in the afternoon and because Sher Khan had to attend a meeting.

I: If we had stayed for lunch, what would you have eaten?

Ali Hassan: I would have eaten only ghi. I would have eaten only soup, without meat.

I: Do you refuse to eat meat in the houses of all Sunnis or only in the houses of Wahabì?

Ali Hassan: Oh, I will never eat meat with Wahabī. But I will eat with Hanafī.

\section{I: But you told me that Malik Amman is Hanafí!}

Ali Hassan: Yes, but this Tablīghī [Malik Amman's younger brother Sadiq] was present! And I am an elder of the Shia, and Shiites would have resented it very much if I had eaten there.
I: Yesterday, Sadiq invoked the ahl-e bayt in his prayer...

Ali Hassan: This he did only for us.

I: I thought that Hanafī Sunnis also paid respect to the ahl-e bayt.

Ali Hassan: They only say that. Orally they do, but not with the heart! And Wahabi do not do it at all.

I: Your son Rasul told me that he had stopped visiting their house.

Ali Hassan: He is angry with them because they gave their granddaughter to a Panjābì. I was angry, too, and I asked them, "Couldn't you find somebody here?" So far away, that is bad for the family. It is bad.

Ali Hassan's different identities had brought him into a fairly strained situation during the visit, and he had tried to do justice to both his religious and his kin affiliation. Most people in Gilgit would have chosen another solution: They would simply have refused to visit their Sunni relatives on the occasion of the wedding. In fact, few people still see their relatives of the other sect on such occasions. But Ali Hassan was very determined to take the obligations arising from kinship and qōm membership seriously, and therefore he had gone to visit Malik Amman and his family. At the same time, he was loyal to his sect and had really felt unable to attend the wedding, including the meal. The problem was not that we stayed only a short time; only a small portion of the wedding guests actually attend the ceremony. Rather, the celebration of a marriage is an occasion to express and to renew community and relationship, and the most important instrument for this purpose is the feeding of the guests. I had attended many weddings with Ali Hassan, and we had always at once been served a rich meal of meat, vegetables, rice, bread, and sweets. Mostly we had left immediately after the meal, but no one leaves a wedding without having been served a meal.

\section{Identities and Différance}

Ali Hassan embraced and enacted a number of different identities. In the context presented here, only his religious affiliation, his $q \bar{o} m$, and his kin relations were significant, but in other circumstances identities derived from speaking Shina or coming from Gilgit and from a particular neighborhood could have assumed importance. These identities are markers of difference, but this difference is not all-embracing. The differences are not separate and do not compartmentalize the person. Of course, speaking a language is different from belonging to a religion or a kinship group, but these identities are still related. They are related because they are embraced by the same person/self, and this relation is crucial for their significance. 
Writing about postcolonial and postmodern identities on the European and North American scene has often adopted Jacques Derrida's term différance to conceptualize identities and the processes they engender (e.g., Brah I996, Hall I990, Radhakrishnan 1987, Rattansi I994). In his lecture "Différance," Derrida (I982) replaces the letter " $\mathrm{e}$ " of différence with an " $\mathrm{a}$ " to call into question the fundamental opposition between the sensible and the intelligible and to explore how the two are related to the process of signification. He draws on Saussurean and structuralist linguistics, which points to the arbitrariness of the relation between signifier and signified, and maintains that meaning is more an outcome of position and relationship - that is, differencewithin language than one of reference to nonlinguistic objects. If difference is what makes meaning, perception, and cognition possible, then différance is was makes difference possible. It is something remote, something before, pre-, that cannot be experienced and cannot even be said to exist because experience and existence require difference (for example, the difference between the existent and the nonexistent). But where difference can be realized, différance is already dissolved. It is essentially volatile. Derrida emphasizes that différance is not even a concept. However, he proceeds to a provisional semantic analysis of différance and points to the conflation of two meanings in the word, both derived from the Latin verb differre. One meaning is the conventional meaning of difference, "to differ." The other is related to "to defer," that is, "to cause delay," "to temporize," "to dislocate."

The second meaning is fundamental to the process of signification. The sign is put in the place of some entity because the entity itself is not present. The sign is, then, a deferred presence; it is both secondary and provisional. But the sign does not only refer to a thing; it is not only representational. It essentially points to other signs that surround it. It is inscribed in a network of signs (or concepts) and signification, a play of differences that constantly refer to other signs and concepts. Changes of signification are spread and reproduced through this network, producing transformations of distant and seemingly unrelated elements. This play of differences, différance, is the precondition for signification and conceptualization. Signification is possible only if a present element refers to another, absent element some aspects of which it thus takes in and if it simultaneously can itself be taken in by a not yet present element. Différance, then, points out that meaning is neither atemporal nor identical; it is continuously moving and changing.

It is this idea that is appropriated by much contemporary writing on identity. Identities are structures of signification that are subject to différance, that is, to the play of differences. The concept of différance introduces a strong impulse of deconstruction into conceptualizations of identity. Identity, then, is not foundational. The identities embraced by a person do not remain the same, identical. Their meaning is constantly being transformed because they refer to each other. They have to be concerned with one another. This change has no beginning and no end. Avtar Brah (1996), for instance, discusses the reflections on one another of identities such as, in Britain, being black, immigrant, woman, and perhaps also lesbian, belonging to a certain class, and being engaged in a struggle to realize particular political objectives. Brah points to the intersectionality of identities: they are not different to the extent of not affecting one another but are all playing a game in the same field, be this a person or a set of power relations in a society (the two, of course, cannot really be separated).

The case of Ali Hassan and, generally, the structure of society in Gilgit show that such an understanding of identity is promising not just for the conceptualization of identity processes in the diasporic periphery of the postcolonial metropolis. The identities embraced by Ali Hassan are not just different but necessarily relate to one another and thereby change in meaning. Polarization in Gilgit stressed the importance of the mutually exclusive identities Shiite/Sunni and demanded the subordination and neglect of other identities. But the effort to organize an assembly of all Yeśkun and the interpretation of the religious dispute as a conspiracy of Șin against Yeśkun show that the impetus to neglect qōm identity provoked resistance which attributed renewed importance to precisely this identity. Not only is there competition between antagonistic groups engendered by different identities of the same dimension (such as Shiite/Sunni in the field of religion) but also there is strong competition between identities of different kinds (such as religious versus qōm or kinship). A shared identity does not have the same meaning for everyone who embraces it. For a Shiite with close Sunni relatives, being Shiite may engender inner conflict and ambivalence (how to reconcile the two identities? how to act toward Sunni relatives?) that does not affect an individual without such relations. A person has to move through this maze of competing and antagonistic identities. Intersectionality and différance prevent the person from realizing and enacting the "pure" signification of a certain identity because competing significations must be taken into account. One identity subverts the other. Ali Hassan cannot simply visit his relatives in Napura on the occasion of a wedding because he has to take into account that they are not only relatives but also Sunnis. Their being Sunnis affects their identity as his relatives and $q \bar{o} m$ fellows, giving it a new and not yet fixed meaning. Ali Hassan struggles through the visit and ends up with relatives with whom he cannot share a meal. Still, they are his relatives, an identity which, for him, is not denied by their being Sunnis.

This différance of identities creates considerable ambiguity for the actor. It works against the clear-cut delimitation of categories of people that have traditionally been constructed by the social sciences. There are almost no "pure" Sunnis but only Sunnis that are also Șin or Yeśkun, speakers of Shina or some other language, residents of Gilgit or another place, and so on. The purest Sunnis, those who are nearly unambiguously "others," different, are those with whom no other kind of 
relation can be found, such as immigrant Pashtūn or Panjābī. But différance does not stop here, for Malik Amman's granddaughter married a Panjābī. Thus, new relations imparting new significance to differences are continually being created.

This ambiguity evolving from crosscutting identities has two aspects. On the one hand, the violation of supposedly clear-cut boundaries is viewed with intense suspicion. Much human action and cognition is devoted to the creation of order, and that entails difference. Ali Hassan, his son, and probably most members of his family resented the marriage of Malik Amman's granddaughter very much. Difference and order crumble if relations are built with those who, like Panjābīs, are supposed to be totally different, that is, originally unrelated. But these people are completely different only from the perspective of the Shiites of Gilgit. For Sunnis in Gilgit like the family of Malik Amman, they are not as different because they at least share the religious affiliation. The movement of différance, the creation of ambiguity cannot be contained without conscious efforts to reconstruct difference (which is what Ali Hassan did when he refused to share the meal with his relatives) - and even then différance can only be deferred, for Ali Hassan is now related, however distantly, to Sunni Panjābīs. At the same time, ambiguity is not a threat but a great resource. Différance continuously restructures the social world, creates new relations between humans, and opens new opportunities for action. Differences do not entail ultimate limits, because their meaning can change and can be changed, paving hitherto obstructed ways for human relations. Ali Hassan can visit his relatives even though they are Sunnis, and he can try to do it in a way that plays with the ambiguity involved.

\section{Self}

The close look at persons embracing a plurality of identities indicates that it is indispensable to distinguish between (shared) identity/identities and self. The way Ali Hassan made his way through the visit and explained it in retrospect shows that he was able to manage his identities. This ability to manage different identitiesto manage difference-is an important aspect of the self. Put the other way round, to conceive of a plurality of identities that can simultaneously and/or subsequently be embraced and enacted by the "same" person we need something that somehow remains the "same" - in spite of the various differences entailed by different identities. What remains the same is a reflexive sense of a basic distinction between the self and everything else. In what follows I will tentatively treat the self, following Hallowell (I955), not as an independent and autonomous entity (according to the paradigm of the Western self) but as that reflexive sense that enables the person to distinguish self-consciously between himor herself and everything else. The self creates the basic difference to which all ongoing experience is subordi- nated. This reflexive sense may also entail a sense of consistency and continuity simply because the basic difference persists. The basic difference between myself and everything else can be endowed with differing meanings, transmitted culturally or engendered by the experiences of the individual life history. No matter whether the self is represented as a quite autonomous and independent being, endowed with agency, or as essentially dependent on others, the basic difference persists. Although the meanings attributed culturally to the self may thus vary, for example, in terms of the degree of autonomy it is conceded, an implicit general meaning of this minimally defined self has to be taken into account: The reflexive distinction between the self and everything else entails at least some agency. I understand "agency" here as the ability to act on one's own account (although with reference to others), that is, in Hannah Arendt's (I958) sense, as the capacity to take the initiative, to make beginnings. This understanding certainly does not include the propositions that action is unconstrained, committed without regard for others, and that it leads to the intended outcomes. The actuality of this minimum of agency may be expressed only negatively in a constant concern not to comply with the culturally given norm of not displaying agency and individuality. Geertz's (1973) example of the stage fright that pervades persons in Bali because they must not be publicly recognizable as individual selves and actors points precisely to the fact that agency is an integral ability of human beings - an ability which continually threatens the culturally established norm of nonindividuality.

What is the relation between the self and its identities? If the self assumes the identity of belonging to the Shia-my example-it retains the sense of remaining distinct in that it also assumes other identities not shared by all Shiites. The fact of sharing kinship with Sunnis reflects upon Shiite identity and transforms its meaning (and vice versa). Différance transforming the meaning of identities works within the self and contributes to the sense of distinction between the self and everything else. One's ongoing experiences are subject to this sense of self. The self, then, is an instance superordinate to (though not detached from) the plurality of identities. Whereas these identities can be experienced as a plurality, the self is experienced as one because it is the frame that guarantees the continuity on which the multiplicity of identities is inscribed. But, at the same time, if the self is itself part of a difference, then it is also subjected to différance, that is, it is continuously in motion and subject to change.

The self is not passive. It is important to note the agency displayed by the ability to manage identities. Ali Hassan selected certain modes of action and rejected others. He pursued his action up to a certain point and then took another turn (e.g., in ending the visit). He engaged other persons in his actions. In my understanding, the reflective sense of the self-of being distinguished from others-cannot be separated from this agency. Because all action (that is, the selection of a certain mode 
of action from a range of possibilities) is accompanied by a reflexive monitoring of its outcomes /Giddens I984), acting is synonymous with reconstituting the reflexive sense of the self.

Ali Hassan's sense of self as exhibited in his management of identities is quite strong. His management of identities is far-sighted and rather ingenious. He is very conscious of the differing and conflicting demands raised by different identities and tries to make his way without being torn apart by them. I am quite sure that the fact that we were accompanied to Napura by Sher Khan was itself an element of Ali Hassan's identity management. Sher Khan himself had no interest in the visit. His relation with Malik Amman was distant and mediated by Ali Hassan (Sher Khan was a paternal cousin of Ali Hassan's wife), and, being an important leader of the Shiite community, he was much stricter in relations with Sunnis than Ali Hassan. The visit did not confer on him any symbolic capital or other gain because this wedding was not a very representative event. Rather, it posed a physical danger to him, as he had already been threatened, and Napura was a village with a majority of Sunnis. Finally, the way he behaved during the visit made him no friends. I presume that Ali Hassan took Sher Khan with him simply in order that the blame for the briefness of the meeting and for eschewing the prescribed protocol would fall on Sher Khan and not on himself. It was Sher Khan who almost immediately after our arrival started to press for our quick departure. In the discussion with Malik Amman and Sadiq about whether to stay or to leave, Ali Hassan remained conspicuously silent. Here he preferred to appear not to be an agent but simply to be complying with the decision of Sher Khan. When we left, he simply followed Sher Khan without much comment. Further, Ali Hassan had scheduled the visit in such a way as to evade the immediate question of whether to have a meal in the house of Malik Amman or not. We arrived in the morning, and it was clear that the meal would not yet be ready because a wedding meal requires considerable time for its preparation. Effectively, Ali Hassan avoided open conflict by coming together with Sher Khan, who immediately wanted to leave, and by coming early enough to be sure that the meal, so heavily burdened with symbolic content, could not quickly be served. He was interested in the visit because Malik Amman was a close and esteemed relative, but he had to take the religious difference into account.

Malik Amman and his family also tried to manage identities. They were eager to play down the religious significance of the visit. By invoking the ahl-e bayt in his prayer, Sadiq even committed an act of outright selfdenial, for that is what saying such a prayer amounts to for a strict Wahabì. And Malik Amman's son, when accompanying us to the jeep, explicitly pled for disregarding the religious difference and simply acting as relatives instead. Obviously, he was not convinced by Sher Khan's assertion that we had to leave only because he had to attend a meeting.

Ali Hassan's strategy of identity management en- abled him to remain to a certain extent loyal to both contradicting identities. He was loyal to his relatives in that he visited them on the occasion of the wedding, and he was loyal to his religious community in that this visit was strictly limited and did not include commensality across the borders of the sects. Where wedding and hospitality etiquette was violated, it was not his fault but Sher Khan's.

When we discussed the visit the next day, Ali Hassan entered a second stage of self-representation. Here he presented a consistent self by effectively denying conscious efforts and strategies of identity management. ${ }^{15}$ He tried to represent himself simply as sincere and not as consciously manipulating identities. According to him, we did not leave in order to eschew the compromising meal. He even asserted that he could have stayed until the meal was served and then partaken of it, simply refusing the meat and eating only plain "soup." This assertion is of course grotesque. A wedding meal without meat is no wedding meal at all. Hospitality, in any case and even more so at a wedding, requires that the host offer his guest the best pieces and practically force the guest to take them. It would have been an insult if Ali Hassan had rejected precisely the meat which Malik Amman was expected to put in especially rich pieces on his plate. In the context of the Shiite-Sunni conflict, where everybody knew what was at stake, that rejection would have amounted to a public reproach of the host as a käfir.

By outlining to me this hypothetical strategy of partaking in the meal without consuming meat, Ali Hassan was denying to me that we had left Malik Amman's house because of religious considerations. He was trying to convince me, as he had tried to convince our hosts, that our departure was due only to Sher Khan's obligations. This way of interpreting his action enabled Ali Hassan to present himself as not having succumbed to the pitfalls of conflicting identities or the pressures of the conflict between Shiites and Sunnis. According to his self-representation, his action was not predetermined by a field of polarized identities. He was eager to display his agency, that is, his ability to act rather independently in accordance with his own values and motivations in a social context heavily burdened with constraints on the range of interaction.

In Ali Hassan's case, the consistency of the self rests on the ability to describe one's actions and ideas in a more or less consistent way-even if this is questioned by an interlocutor. Therefore, we can speak of a narrative self. An important element of Ali Hassan's narra-

I5. That Ali Hassan was very conscious of what had been at stake on this occasion became obvious when, a few weeks later, the wedding of one of his own sons was celebrated. On that day he and his sons several times speculated about whether anyone from Malik Amman's family would attend the event. In the end no one came from Napura, but Malik Amman's second brother sent a jeep with a driver to transport Ali Hassan's family to the house of the bride's family. They practiced their own management of identities by contributing something important and highly valued to the celebration without coming too close to compromising meals. 
tive strategy of self-representation was agency: He decided how to act, choosing his mode of action from a number of available alternatives. He could even have stayed and partaken in the meal-eating only soup. The narrative self results in the creation of a personal image. This image has to relate to the identities embraced by the self. Identities are indeed connected with "given" or "shared" images such as stereotypes, expectations, and roles, but the self is not exhausted by them. Identities can be considered as building blocks for the construction of an image of the self. These blocks are not simply laid as they are supplied but are trimmed and given forms that can be incorporated into a more or less integrated whole. That is, identities are interpreted by the acting human being in specific ways.

My description of Ali Hassan's representation of a more or less consistent self obviously contradicts Ewing's (I990) depiction of such self-representations as illusory. From her conversations with a young Pakistani woman who rapidly shifts through an array of contradictory self-representations while talking (e.g., from an obedient daughter to a self-assertive student) Ewing concludes that the self-experience of consistency is an illusion based on the fact that ruptures and shifts of selfrepresentation are not recognized by the individual as long as each representation fits appropriately into its particular discursive context. The (illusory) experience of wholeness and consistency of the self then rests on a supposed "slicing" of (contextually different) experiences into disconnected segments. Inconsistency would enter awareness, according to Ewing, only if this continuous shifting of self according to circumstances were hampered or if a self-representation were to conflict with the context in question.

But this consistency-enabling slicing of experience is possible only as long as a level of pure discourse is not transgressed. Ewing's interlocutor can execute her shifts in self-representations without becoming aware of inconsistencies only so long as she is speaking with her anthropologist interviewer, dissociated from any social context of practical relevance. If she had performed the same shifts of self-representation in front of her parents, they might have strongly reminded her that there is a contradiction between the representation as obedient daughter and the one as self-assertive student. What I am calling for paying attention to in anthropological analysis is a representation of the self that emerges only after the conscious experience of such conflicts in social interaction. In contrast to the self-representations (which I would call "identities") of Ewing's interlocutor, Ali Hassan's self cannot avoid the conflict between being a relative of Malik Amman and being a member of a different sect because he has to deal practically with both. He could do it in pure discourse-as he did by asserting that he could have partaken in the meal while rejecting the meat-but he could not do it in practice. However, he was displaying a self attempting to deal precisely with such contradictions. Such a self could probably be discovered in Ewing's young woman if she were accompanied through conflictual practical mo- ments of her life-through situations in which she would perhaps be trying to be an obedient daughter but nonetheless to pursue higher education and to work.

The narrative self, the personal image developed and displayed in such situations, certainly cannot remain the same. It is transformed as the actor relates to other contexts and to other co-actors, integrating him- or herself into other networks. Action restructures social relations and results in a reinterpretation of social contexts, and thus the meaning of the distinction from othersthe reflexive sense of self-changes. The self is not distinguished from all others in the same way. The difference (identity) distinguishing Ali Hassan from Sunnis is different from the difference distinguishing him from Șin. Accordingly, the contents of the self-the image and representation that are displayed-do not remain the same for an outside observer looking at the individual as he or she moves through changing contexts.

To counter mistaken conclusions I have to emphasize that it is not my intention to present Ali Hassan as a autonomously acting individual, as a voluntaristic self. This of course he is not. He was obviously taking social and cultural constraints into account. The problem he was trying to solve with his mode of action was preestablished by a long history of power relations and struggle. He could not act as if there were no conflict between Shiites and Sunnis, and he could not achieve the aims of his action completely undisturbed. The others were acting too, advancing conflicting aims, interpretations, and representations against Ali Hassan's. He could not avoid a certain conflict with his relatives at Napura that might have produced some estrangement, and he could not dispel my doubts about the story he told. Also, his display of agency in his narrative was curtailed by these constraints. In fact, in order not to appear to have been determined by religious antagonism, he chose to delegate his agency to the schedule of Sher Khan. But it is important to realize that, entangled in such constraints, antagonisms, and half-realized aims, he displayed a strong sense of self, setting himself apart from others and trying to manage the identities through which he related to others in the way that seemed most beneficial to him.

Ali Hassan is not representative of the scene in Gilgit. To the contrary, his mode of action was quite exceptional. Facing the constraints of a deeply entrenched polarization between Shiites and Sunnis, most other persons in Gilgit would have decided to put one identity (probably the religious one) first and to act accordingly - that is, they would not have visited their kin of the other sect on a similar occasion. And, of course, social ideology in Gilgit gives as much weight to the benefits of one's community and as little importance to selfinterest as in other South Asian societies. Here too, individuals define themselves in terms of their affiliations. All this does not, however, render Ali Hassan's example valueless. What Ali Hassan shows us is that even in a seemingly "anti-individual" social and cultural setting it is possible to develop a strong sense of self. He teaches us that recording values and ideologies 
is not sufficient to arrive at a fairly correct image of social reality. To analyze cultural conceptions of the person tells us little about what persons thus conceived do and how they (try to) appear. And Ali Hassan's action points out that the ambivalence created by a multiplicity of (in each case constraining) identities creates a space for nonpredetermined actions of the individual.

\section{Culture and Self}

Conventionally, psychological anthropologists speak not about the self as an actual reflexive center of the person but only about cultural concepts of such a center. This distinction is crucial, as it relieves anthropologists from giving importance to "actual selves" and from reconceptualizing the relationship between culture and self. Sometimes it seems to be assumed that, cultural norms and concepts aside, persons of course feel, act, and are experienced by others as individual selves. But this does not apply to all cases. In the discourse about non-Western selves, the signified and the signifier are not always kept apart. Geertz, for example, wrote about the actual self-representation of the person and not about some cultural conception, as Spiro (I993) emphasizes. Similarily, Dumont (I970) conflates the cultural norm of nonindividuality in India with social reality. Given the importance of the concept of culture in anthropology and its conventional meaning, it is clear that a distinction between a cultural conception of the self or person and the "actual" self or person cannot be strictly maintained. Culture is understood not as something ephemeral but, according to a dominant view, as a "power" constituted by systems of shared meaning that is effective in shaping social reality. Culture, Geertz (I966) tells us, is not only a model of but also a model for. Accordingly, Shweder and Bourne (I984) compare explicitly cultural concepts of the person and not "empirical agents," as Dumont would say, but they end up describing how a particular concept goes together with a certain style of socialization of the person. The concept makes its mark on the "actual" person. The two cannot really be separated.

An interesting example of the analysis of cultural concepts is Marilyn Strathern's (I990) comparative study of Melanesian culture. She rejects a number of foundational categories of anthropological and sociological discourse for her analysis because they do not fit into the conceptual/cultural world of Melanesians. Among other things, Melanesians do not recognize any problematical relationship and opposition between individual and society; they do not even have concepts of these entities deemed basic in most Western discourse. Strathern construes the Melanesian concepts of self/ person/agent/individual in sharp contrast and opposition to Western concepts. The overall distinction between the two types of culture is provided by the metaphor of gift society (Melanesia) versus commodity society ("the West"). In a commodity society, the self is imagined as the author and cause of actions which, along with their products, belong to it. Alienation of an other's products therefore potentially affects the other's self. There is no such possessive and potentially exploitative relationship between selves in Melanesia, according to Strathern. Here, a self/agent is not the author of its action because it always acts "on behalf" of an other. Action aims at the transformation of a relation between persons and at the same time is caused by this relationship. Because persons are constructs of relations, action results in the transformation of persons. This case of strict sociocentrism raises a number of questions. Stephen (I995:I42) points out that the analysis hardly leaves a place for a conscious self in the sense of a person aware of being an agent. Indeed, action and agency seem to be reduced in Strathern's description to re-action and "re-agency," as the agent never contains its cause within itself. The appropriateness of the (Western) concepts of agency and action to this case, then, remains debatable. Further, doubts remain whether Melanesians are "really" as different as they are portrayed. Carrier (I996b) argues that the general description of Melanesian society as a gift society implies the extension of exchange relations pertaining specifically to the ritual sphere to the whole of social life. This fails to take into account that the people of New Guinea and other islands are of course integrated into a market economy and therefore partake of commodity relations as well. What is missing, accordingly, is the specification of the particular circumstances under which people in Melanesia understand and represent themselves in the manner portrayed by Strathern. In my understanding Strathern's approach is also questionable because it constructs a rather biased model of Western concepts of agency and the self. She emphasizes the singularity and possessiveness of relations between agents and their acts or products in the West, in which any intervention by others is regarded as an intrusion (Strathern I990: I 58). She takes as a general model for the concept of human activity in the West what according to Arendt (I958) is but one modality of the human vita activa: work. Contrary to work, action in a specific sense is characterized not by the possessive singularity of a relation between the agent, who does the work, and his product but by the fundamental plurality of human agents and their mutual relationships. Acting always relates to other human beings and takes these others into account, much as, according to Strathern, acting in Melanesia is always acting "on behalf" of someone else. Of course, Strathern is writing only about cultural concepts, not about actual selves or individuals in Melanesia. Such actual selves-people talking and doing many different things-are conspicuously absent from her book. The question remains whether Strathern's synthesis of Melanesian concepts is possible precisely because of this absence.

In addition to the distinction between concepts and actual selves, there are other distinctions that are difficult to maintain. Many writers have noted that the related concepts "individual," "person," and "self" get mixed up in the debate, causing misunderstandings and 
rendering comparison difficult. Consequently, Harris (1989) calls for keeping them strictly apart and proposes definitions intended to facilitate an ordered discourse. ${ }^{16}$ I doubt whether this is really feasible. Ingold (I99I) strongly challenges the separation of the biological organism (the individual, in Harris's terms) from the person and self, arguing that the process of becoming of the human organism and of the human person/self is in fact one. Further, Harris's demand for a separation of concepts succumbs to a logical fallacy that is very common in anthropological approaches to intercultural comparison. She takes analytic terms to elicit emic understandings, that is, she uses universalist tools for relativist purposes. The three categories are derived from "West$\mathrm{ern}^{\prime \prime}$ discourse (although they are not always consistently distinguished within this discourse), but they are appropriated as universal pigeonholes for intercultural purposes. However, if we assume that concepts of the self vary cross-culturally, how can we suppose that a distinction between self, person, and individual is in all cultures maintained consistently according to our analytic understanding-or even that it is maintained at all? These terms are not really kept separate in Western cultural understanding and discourse; how, then, can we expect that they are distinguished in other cultures' discourse? ${ }^{17}$ Even if we analytically distinguish these three aspects of the human being, we have to assume that they heavily influence one another and reflect upon one another and that keeping them separate is more a useful fiction than a cogent representation of human life. ${ }^{18}$

Both cognitive and interpretive anthropology have caused anthropologists to give more importance to how people think and what they say than to how they act. Accordingly, cultural concepts of the self have been analyzed much more thoroughly than the way selves appear in the actions of humans. This privileging of concepts carries considerable danger, because it rarely asks who actually holds which concepts about whom. The ontological status of "cultural concepts" depends on a particular understanding of culture and echoes Durkheim's concept of "collective representations," which British functionalists made synonymous with social and cultural determinism (see Kuklick I991:I20). This idea was taken as justification for the fact that social anthropology gave little attention to the individual, regarding the social as its only object. Malinowski argued, accordingly, "As sociologists, we are not interested in

I6. In Harris's understanding, "individual" refers to the biological aspects of the human being, whereas "person" refer to its social and "self" to its psychological aspects.

I7. For example, La Fontaine (I985) argues that the Gahuku-Gama of Papua New Guinea do not recognize this distinction.

I8. Morris too argued for a similar distinction between concepts ("human subject." "person," and "self," in his case), but then, knowing that this distinction cannot practically be maintained consistently, excused himself for not doing so, trusting "that this lack of precision in the use of terms will not disturb the reader" (I994:I6). Under the general title "Anthropology of the Self" he then discussed "conceptions of the person" (chaps. 6. and 7). what A or B may feel qua individuals ... only in what they feel qua members of a given community" (I922: 23)..$^{19}$ In this line of thought, the analysis of cultural concepts of the self (of the person, etc.) only apparently gives attention to the individual human being in studying its "collective representations."

The conceptualization of the relation between individual and society has since been reshaped, moving away from both social determinism and methodological individualism toward a more dialectical understanding in which individual and society are related by mutual constitution (or "structuration," in Giddens's [I984] terms). Consequentially, what A and B feel (do, say ....) as individuals and as members of society cannot be separated, because as individuals they are always members of society, engaged in an ongoing process of mutual structuration and transformation.

This reformulation has to be taken into account in the anthropological discussion of "cultural concepts." Everyone will agree, I suppose, that concepts are held and expressed not by cultures but by human beings. Who, concretely, voices a concept that is accorded the status of a "cultural" one? Asked differently, which people do anthropologists ask in order to elicit a cultural concept? Can we assume that the individuals who are supposed to belong to "a" culture share the respective concepts? Or do we have to take differing understandings related to differential interests, (subject) positions, and individual exegesis into account? ${ }^{20}$

It is sometimes argued that concepts of the self or, for that matter, the person or the individual are culturally variable because all people are not always conceded to be persons everywhere. Slaves in ancient Greece were not considered persons because they did not possess the rights of a free Greek, and it is argued that prisoners in Nazi concentration camps were effectively denied personhood by the brutal system of repression (Harris I989). But what is at stake here is less concepts of the person than strategies of domination and extreme oppression which may also find their expression in particular concepts and their application to others. However, we should not be content with recording that Greek slaves were not persons because their masters did not regard them as such or that in concentration camps

I9. Among the founding fathers of anthropology, Boas granted the individual more importance, allowing it not only to be determined by society but in turn also to change society. He criticized anthropology for not paying enough attention to the ways in which the activities of individuals affect their culture (I982:268). Unfortunately, this was not sufficient to give American anthropology a significantly different perspective in this regard. Kroeber's (I9I7) conceptualization of culture as the "superorganic" removed it completely from the reach of individuals, and Benedict (I949) reduced the individual to a culture-bearer subject to cultural determinism.

20. Spiro (I993), for instance, argued that the persons from whom Shweder and Bourne elicited their "Western concept of the self" might have influenced the contents of this concept because they included a number of psychologists who were professionally engaged in the exegesis of the self. 
there was a systematic attempt to destroy the personhood of prisoners. We have to go on to ask whether slaves or prisoners complied with the verdict of their masters and oppressors or whether they had their own subversive strategies of maintaining and reconstructing personhood and self even under very unfavorable circumstances. In the Nazi concentration camps such strategies were extremely risky. If they were discovered by the guards, prisoners were subjected to extreme punishment, including, very often, execution. But what strikes me is that even facing death many prisoners were not ready to surrender their own and their fellow prisoners' personhood. ${ }^{21}$ We may arrive, then, at the conclusion that to be or not to be a person is less a question of cultural concepts than of particular ways of interaction between individuals positioned in a complex system of power relationships who struggle to maintain or to improve their position with regard to others. Consequently, attention to actual individuals is required. If we thus draw a connection between relations of power and the application of concepts of the self/person to others, we also have to ask from what position of (representational) power anthropology is able to deny or to play down the self or individuality of its others.

In much recent anthropological discourse, culture, the basic concept of the discipline, has dissolved into a stream of cultural processes with uncertain places and boundaries. No longer a fixed body of traditions, meaning, or other elements, culture has become something constantly "in the making" - an ever-changing outcome of social processes and struggles (Fox I985; cf. Barth I989, I993). The more the concept of culture was appropriated by political discourse for the sake of objectifying difference (e.g., Stolcke I995), the less fixed and corresponding to an object "culture" became in anthropological writing. Wicker, for instance, defines culture simply as "the ability to produce reciprocal symbolic relations and to form meaning through interaction" (1997:39-40). But if culture no longer exists in the sense of $a$ culture, shared by the members of a society, what is left for non-Western people-those without a self who are supposed to have a cultural identity insteadto derive their identity from? And if people embrace not only one identity but a multiplicity of identities related to changing contexts, what is there in them that tells them when and how to change from one identity to another (and to which other)?

In the older, reified understanding, culture and iden-

2I. A number of very moving accounts of survivors of Auschwitz that can be read in this way are collected in Adler, Langbein, and Lingens-Reiner (I994). In one testimony, Józef Stemler describes how one of his fellows was trampled to death by an SS officer while they were digging trenches outside the camp. A Polish priest who had witnessed the scene left his place, crept to the assassinated one, cleaned his face of blood, and closed his eyes, knowing that if his action was discovered by the SS he would suffer the same fate. Here the prisoner was not ready to give up the personhood of his murdered companion and took the risk of according him at least rudimentarily decent treatment after death (Stemler 1994:22). tity seemed to be conceptual twins, firmly bound to one another. Culture was something shared that characterized a group collectively, just like identity. ${ }^{22}$ This "sharedness" practically amounted to a premise diverting attention from the individuality of the people anthropology was studying. No matter whether these people possessed individuality or not, anthropology was interested not in what distinguished them individually but only in common, shared elements.

The evolution which the concepts of culture and identity has undergone has transformed them in related and quite similar ways, but this transformation has made it difficult to conceive of a relation between them without falling back into the trap of reification, that is, without momentarily reifying at least one of them. If identities are floating like cultures (or if cultures are not even "something" floating but the flux itself), we have to look for a relatively stable point from which to observe the flux. If culture is the outcome of a struggle (as Fox [1985] maintains), we have to look for those who are struggling. Put differently, if cultures and identities are not simply shared, those who do not simply share and who can no longer be subsumed under these concepts gain renewed importance.

I am here exploring the possibility of conceiving of the self (used here as a generic term including "individual," "individuality," "person," etc.) as this relatively stable point. Certainly, we have to be careful not simply to subscribe to the objectification and universalization of the Western self. I am not advocating an understanding that in every cultural context the self embodies the highest values. Cohen (I994) warns us not to confuse individuality with individualism. Rather, I am arguing that the self should be taken as a universal like culture, without thereby predicating much about the contents of the self (or of culture). Not too long ago it was by no means superfluous to discuss whether all humans "possessed" culture. Anthropology has played an important role in establishing the now generally accepted view that culture is a definitional characteristic of the human being. Similarly, I would like to see anthropology making the same effort to develop the understanding that there is no human being without a self and that it is indispensable to anthropological practice to be attentive to these actual selves. These efforts do not necessarily have to be based on a shared understanding of the self. That the meaning or definition of "culture" is in dispute is quite independent of the fact that culture as a basic quality of humanity remains uncontested. And just as anthropologists discuss the significance and function of culture for human action and society in general, detached from specific cultural meanings and contents, I want to argue that we should also direct our attention toward the importance of the self, detached from particular cultural conceptions of the self. In my view, culture and self are complementary concepts that

22. See, for example, LeVine's (I984) description of culture as consensus. 
have to be understood in relation to one another in order to avoid the reification of one or the other. It is not sufficient to limit the study of self in anthropology to the study of cultural concepts of the self, because this approach implicitly or overtly accords primacy and determining power (that is, ultimately, agency) only to culture. Social psychology is frequently and rightly reprimanded for not taking culture into account. The opposite charge can surely be leveled against anthropology: that it is one-sided in giving importance only to culture, reducing the self to a product of culture and often remaining blind to individual motivations, aims, and struggles.

Of course, the charge may easily be raised against such an approach that it is wrongly imposing a "Western" understanding on other cultures (after all, so many anthropologists have been determined to show that there is no universally shared understanding/concept of the self). But the same applies to the concept "culture": it too is imposed on others. The imposed, almost hegemonic usage of "culture" is not even complemented by a discussion about culture-specific meanings and concepts of "culture" (as in the case of the self), and I have never heard it said that a group lacking an appropriate indigenous concept for the Western notion of "culture" simply possessed no culture. ${ }^{23}$

\section{Conclusion}

The purpose of this paper is more to raise a number of critical questions than to provide ready answers. I do, however, want to suggest how the self might be envisaged by anthropology as a universal which, like culture, is a definitional aspect of humanness. Such a conceptualization of the self has to avoid both the Scylla of voluntarism (as laid down in the Western self as conventionally understood) and the Charybdis of cultural determinism (as embodied in the non-Western nonself). In my view, this conceptualization of the self has to be developed from heightened attention to the human capacity and necessity for action. An inevitable premise is that all humans are able and required to act, which means that there is no culture (or identity) acting for them or uncontradictably prescribing which mode of behavior must be chosen in any situation. This becomes utterly clear in situations of plural identities, where individuals are obviously not bound to a cultural consensus but exposed to a plurality of conflicting perspectives and interests and must, like Ali Hassan in his uneasy wedding visit, make their way through a maze of different identities. Attention to selves accordingly demands "ethnographies of the particular" (Abu-

23. For example, in contrast to her rejection of Western concepts of "society" and "individual" for the discussion of Melanesia because these concepts are not held by Melanesians, Strathern neither rejects the concept of culture for her analysis for the same reason nor argues that its use is justified because it belongs to the conceptual universe of Melanesians too.
Lughod I99I) that examine what people actually do in the specific circumstances of their daily lives.

Action requires a self that reflexively monitors the conditions, course, and outcome of action. This reflexivity includes the consciousness of the basic difference between the self and everything else which I have proposed above. My argument that agency is characteristic of the self and the self is a precondition for action may seem circular, but in fact the two or, better, the three aspects cannot be separated: agency, reflexivity, and the self go hand in hand, each requiring both the others. Drawing such a close connection between the self and agency avoids the danger of voluntarism, because the self-reflexive monitoring of action also includes the recognition of conditions for and constraints on action, that is, the limits of agency.

In the dichotomous conceptualization of Western and non-Western selves so prominent in anthropology, the most salient quality of the first is said to be egocentrism, whereas the second is taken to be characterized by its sociocentrism. I suppose instead that egocentrism and sociocentrism are integral aspects of every self. Agency requires both reflexive monitoring of the self and monitoring of the self's relationships with others. Accordingly, Ali Hassan, in his wedding visit, acted both ego- and sociocentrically: He weighed his contradictory memberships and decided on a mode of action that seemed most beneficial to him because it severed neither of them. Selves are of course not uniform, and therefore the prominence of either of these aspects may vary from case to case, as may the consistency of selfrepresentations. Which of these aspects is represented as most salient is also a question of the perspective and the interests of the observer.

It is somewhat ironic that some anthropologists are beginning to argue for the importance of the self of their non-Western subjects of study only now that the self and subject in the West (including the Western anthropologists' own selves) have been seriously challenged. Here, the autonomous, egocentric Western self is reduced to a "subject effect" (see Spivak I988:I2-I3), and agency is seen as an "effect of heterogeneous networks" (Law I994). The subject, or self, and its agency are understood as a product of discourse and social/historical conditions. This deconstruction of the Western self strips off its hypertrophy of autonomy and self-determination and therefore makes possible a more modest conceptualization, but deconstruction should not be taken too far. Social constructivism too carries the risk of reductionism and determinism (Calhoun I994). Michel Foucault, one of the prime movers of this deconstruction (although he too, in the language of the movement, is only an effect), was in his later writings quite anxious not to destroy the subject by deconstructing it (Foucault 1982). After all, the question of whether something (the self, agency, the subject) is a cause of something or an effect of something else is a question of time and perspective. It can be either, depending on the observer's emphasis.

My paper intends to blur dichotomous boundaries 
and not to construct new ones. I do not want to argue that the selves of all people of the world are almost the same or essentially similar. I am not of the opinion that "others" are "really" (that is, anthropological othering apart) like the "self"- or, to repeat, that the others' selves "really" approximate "our" ("Western") model. I want to endorse the view, however, that our selves and their selves are not necessarily as different as many anthropological texts, employing the dichotomy of the self and the other as an a priori of ethnography, portray them. After many decades in which difference was the paradigm for conceiving of the others' selves, it might be useful to try a paradigm of more similarity. To allow for such similarity demands an important methodological reorientation. It requires giving real importance to the actual individuals we work with while studying "culture." This presupposes not quickly and thoughtlessly subsuming them under some social or cultural category but representing them, even in the ethnographic text, as individuals. It is they whom we study, not some superindividual entity. This entity-culture-is only our construction from countless encounters, dialogues, and interactions with actual selves or individuals.

\section{Comments}

\section{AZAM CHAUDHARY Department of Anthropology, Quaid-I-Azam University, Islamabad, Pakistan (ju katzan@ hotmail.com). I5 III 99}

This article may be divided into two parts. In the first part Sökefeld criticises the traditional anthropological approach of denying anthropological subjects independent selves. He considers this denial a result of the absence of Western attributes of the self among the nonWestern subjects and the assignment to them of an identity - a shared self-instead of individual selves. He is of the opinion that the concept of self has emerged as an important element of culture and identity in the post-structuralist deconstruction phase, in which identity is no longer shared but plural. To understand the actions of individuals with a plurality of identities we have to understand the self. He further differentiates this concern from the study of self in social psychology: "Social psychology is frequently and rightly reprimanded for not taking culture into account." He is also of the opinion that "it is not sufficient to limit the study of self in anthropology to the study of cultural concepts of self." In short, he argues that "there is no human being without a self and ... it is indispensable to anthropological practice to be attentive to these actual selves." In this regard his article is an important contribution in that it points to a lacuna in anthropological knowledge and thus brings a new perspective and vision to anthropology.
The second part of the article consists of a case study of Ali Hassan, an inhabitant of Gilgit, a small town in the Northern Areas of Pakistan, showing multiple, contradictory, almost mutually exclusive identities. Gilgit is an exceptionally complex case with respect to the question of identities because of its historical background and regionally strategic (economic and political) location. This complexity is evident from the presence of different religious sects and relatively large groups of different regional, linguistic, and ethnic backgrounds (Shia, Sunni, Wahabi, Ismaeeli, Noor Bakhshi, Pathans, Punjabis, Balti, Chitrali, Hunzakuds, Shin, Yashkun, Kamin, Dhom, and others) in a town of some 50,000. One of Sökefeld's conclusions is that "there can be no identities without selves." This implies that if we want to study identities we must study the self. He defines the self as "that reflexive sense that enables the person to distinguish self-consciously between him- or herself and everything else," and the question becomes how we are to study it. The complex and contradictory identity affiliations of Ali Hassan are exceptional even within Gilgit:

Ali Hassan is not representative of the scene in Gilgit. To the contrary, his mode of action was quite exceptional ... most other persons in Gilgit would have decided to put one identity . . . first. . . social ideology in Gilgit gives as much weight to the benefits of one's community and as little importance to self-interest as in other South Asian societies. Here too, individuals define themselves in terms of their affiliations.

According to Sökefeld the example of Ali Hassan shows the "struggle to act and to present oneself as a consistent self in a situation of plural and contradicting identities." The self of such an individual probably can be located as he suggests, but the question remains how we can study non-Western selves in ethnically and religiously homogeneous settings or in heterogeneous ones in which (as in Gilgit) most people have plural but not contradictory identities. This article does not answer this question. In raising the question of the relationship between identity and self this article opens new directions in anthropological thinking, but the question of the methodology for exploring this relationship in different types of ethnographic settings remains open.

HENK DRIESSEN

Institute for Cultural Anthropology, University of Nijmegen, Postbus 9I04, 6500 HE Nijmegen, The Netherlands. 25 II 99

Sökefeld lucidly addresses questions about changing notions and senses of self in interaction with social identifications and cultural resources. For the past two decades, such questions have circulated widely through departments, journals, conferences, and courses not only in cultural anthropology but also in related disci- 
plines. Moreover, the media and politics have raised similar issues, mostly in essentialist idioms.

At the same time, debates about representation in ethnography have resulted in a shift away from crosssection people performing roles, perceived as passive vehicles of cultural identities, towards active, selfconscious individuals managing composite and fluid identities and manipulating cultural resources. The widespread revival of the life history is part of this paradigm shift.

There is now a burgeoning literature on "identity", to the point that any scholar-and Sökefeld is no exception-writing about this broad theme runs the risk of overlooking relevant literature. Moreover, "identity" has become a shibboleth, too frequently part of an academic litany that presents it as relational, shifting, mixed, constructed, (re-)invented, negotiated, processual, and conjunctural. The repetition of such qualifications has become part of an academic identification ritual. Sökefeld, however, manages to distance himself from the ritualistic use of identity and critically rethinks received ideas about self, identity, and culture.

European notions of individualism (the self as a bounded, stable, cohesive entity) and collectivism (the faceless self determined by society) have deeply influenced anthropological thinking about identity. Sökefeld particularly underlines the impact of the Cartesian notion of the sameness of the self. However, the problem with his brief excursion into the history of "Western" ideas is that he totalizes complex notions and neglects their counterpoints (for instance, Nietzsche's idea of the subject's multiplicity or notions of self in peasant society). Many anthropologists working abroad tend to develop a bias towards the oral and marginal, but when they make statements about "home" they reverse this distortion by referring only to dominant formal ideologies.

One of the overlooked references is the useful little book by Richard Jenkins (I996), a sociologist of symbolic interactionist persuasion who transgresses disciplinary borders between sociology and anthropology. Jenkins concentrates on the pragmatics of identity formation. He maintains that the similarity-difference and internal-external dialectics of identification constitute the process whereby all identities, whether individual or collective, are formed. Rejecting the identity bitsand-pieces model, he embraces a unitary model viewing the self as a rich repository of cultural resources. But whereas Jenkins leaves aside the links between self and culture, Sökefeld is more culture-sensitive and takes self-culture interaction into consideration. His fieldwork in Pakistan offers an instructive case study of identity management in the performances of Ali Hassan. This powerful patron's problematic visit to a wedding is diagnostic of the diversity of identities played out. Although such crosscutting identities mark differences, they do not compartmentalize Ali Hassan's person. His self acts and reflects on multiple identities and is experienced as unitary.

Sökefeld draws far-reaching conclusions from the ac- tions and reflections of one person. He maintains that, although the self is clothed in culture-specific attributes, it is universally endowed with reflexivity and agency. In other words, Western and Pakistani selves are not as different as suggested by the paradigm of difference which is paramount in ethnography. Instead, he makes a plea for a model of "more similarity."

Five brief remarks are in order. First, Ali Hassan stands out as a patron/broker, a specialist in identity management and in this feature a preeminent reflector on and narrator of self, probably more so than many others in his social environment. Second, Ali Hassan's self is more complex than is revealed by Sökefeld in his rendering of the wedding visit. Primary identifications such as gender and age are left out of the picture. Third, Sökefeld's "self-centred" analysis deals with the case of one protagonist in a rather bounded field of interaction. How are we to proceed in more complex social figurations in which many different people are involved? A prosopographic approach that addresses the internal-external dialectic of identity formation obviously involves more than presentations of the narrated selves of prominent figures. Fourth, what is a model of "more similarity" if difference and similarity are inevitably Siamese twins? Such a model requires an explicit comparative approach and not the implicit we-them juxtapositions often found in anthropological work. The self of Ali Hassan is discussed in its particular shapes, whereas the Western self is stereotyped. Fifth, Sökefeld argues for a self-centred ethnography but avoids the burning question how it should be grounded in political economy. In sum, he is strong in his ethnographic attention to a (non-Western) self, but, as always, a lot of hard work remains to be done on how (self-) identities emerge, endure, and change in social interaction and what power resources and cultural flows are tapped in this process.

KATHERINE PRATT EWING Department of Cultural Anthropology, Duke University, Durham, N.C. 27708-009I, U.S.A. (kewing@acpub.duke.edu). I6 III 99

I very much agree with Sökefeld's call for the investigation of the relationship between social identities and the "self." This line of investigation is crucial both for understanding how individuals and societies negotiate rapid social and cultural change and for transcending a scholarly and political gulf between what has often been characterized as "mainstream" anthropology and psychological anthropology. However, Sökefeld does not clearly focus on this issue, casting his argument instead in terms of an effort to disrupt what he sees as anthropology's prevailing tendency to see the "self" in terms of the individual/communal West/rest dichotomy. But this is a point that has been made before, even by some of the very people he suggests are guilty of such dichotomizing.

An effective treatment of the relationship between social/political identities and the self would require a 
clear theorization of each category, of the relationships between them, and of the kind of evidence that would be needed to demonstrate these relationships. In constructing models of the "self," for instance, it is important to consider the kind of data that could convincingly serve as evidence for one sort of self organization or another. The case of Ali Hassan and his "uneasy visit" offers an interesting instance of the skillful negotiation of what I would agree with Sökefeld in calling conflicting identities, but (though Sökefeld suggests that his evidence contradicts my conclusions) it does not illustrate any of the kind of shifts in self-experience that I have considered in my own work on Pakistani women. It is a different level of analysis. Sökefeld provides evidence that Ali Hassan was actively strategizing and very much in control of the situation, carrying through a plan that he had apparently worked out in advance. It is clear that being a skillful intermediary or negotiator is a prominent self-representation for Ali Hassan. (Few anthropologists today, regardless of theoretical approach, would deny the ethnographic subject this skill at strategizing, negotiating, and self-reflexively commenting on these skills. But we are simply not given any evidence that might suggest that Ali Hassan does or does not have other self-representations or whether such representations of self and other did or did not shift during the episode or at any other time. Such evidence would include detailed reports of conversation and interaction that could be analyzed for implicit and explicit representations and positioning of self and other (see, e.g., Labov and Fanshel 1977; Ewing I987, I99I). Lacking such evidence, I am not convinced by Sökefeld's argument for a single underlying self, since the episode is not presented in sufficient detail to reveal shifts of positioning (or lack thereof) that might be seen in other situations and perhaps even detected in this one. Furthermore, evidence of self-reflexivity in Ali Hassan's memories of the event is not the same as evidence for a single cohesive self, a point that Sökefeld seems to be arguing. I doubt that Ali Hassan is selfreflexively aware of every self-positioning he takes, though Sökefeld's argument for a continuous and consistent self would require this.

Nevertheless, I believe we share a key concern, which is to develop useful models for explaining how people negotiate multiple, often conflicting identities.

MARTIN FUCHS

Südasien-Institut der Universität Heidelberg, D-69I 20 Heidelberg, Germany. 28 III 99

Sökefeld's reevaluation of "self" and "identity" points to a larger project intended to reinvigorate the idea of subjectivity and agency in anthropological discourse. This project developed in response to and partly from the same grounds as the "antihumanist" project which for some time had caught the attention of the humanities. The two projects are not exactly in opposition to each other. Rather, the interest in issues of agency and subjectivity can be seen as an attempt to transcend the stale dichotomy of subjectivism and (deterministic) antisubjectivism. What is shared by the two projects is the recognition of contingency in social and cultural matters, but they deal differently with the fact of discursivity.

The reaffirmation of the self as social category develops out of the critique of representation, of othering, but it also underlines the necessity to (re)turn to "substantive" issues of social and cultural theory-theory of action and theory of culture. Although-or, rather, because-culture and society (social structure) was at the centre of the ethnological approach for so long, the question of the subjectivity of members of " $\mathrm{a}$ " culture or society has continued to haunt the anthropological enterprise. Sökefeld emphasizes two points: (I) a strong proclivity in anthropology to deny the existence of selves in non-Western or nonmodern cultures or, alternatively, to suggest that, outside modern Western culture, collective or "shared" identities take the place of the self while assuming that the notion of a bounded, autonomous self is well ingrained in "the West," and (2) a strong ideational bias of much of (cultural) anthropology which leads to a conflation of the conceptual level and what Sökefeld calls "social reality" - of the (culture-specific) concepts of person or self and the "actual selves" met with in social interaction. In objecting to these positions, what Sökefeld brings out clearly is the need to focus on the linkages between cultural schemata, or discourses, and social actors-to attend to the processes of distancing and relating. It is a dynamic, interactional view of self and identity that Sökefeld has in mind, one that allows us to return agency to social subjects while at the same time avoiding a notion of subjectivity as something prior, or presocial.

But some questions remain. In what sense are identities shared (even if only in part)-what does "shared" mean in this context? Does it refer to individual decisions to comply with an identity on offer, to an active choice-to take on an identity or put one aside-or is such an identity passively shared, in the sense of something preconceived to which a member of a certain group has to conform or even submit willy-nilly? Sökefeld suggests that an identity complex is a given but can be of different significance for different actors, but would this not mean that an identity is interpreted and appropriated in diverse ways-that, even if considered as "floating," it is being reformulated and reworked and does not remain "the same"? And, furthermore, how are we to conceive the interaction with other selves with whom the individual self is supposed to share something? How is commonality (re)produced, perhaps promoted or enforced and probably differently with respect to religious beliefs and practices and with respect to kinship? The self, for that matter, cannot be considered as somehow aloof, a stage manager of differences which are subordinate. Not only, as Sökefeld concedes, can the self not be seen as detached from the identities it relates to but it has to be seen, in a qualified way, as constituted by them. This is not meant, of course, to 
reintroduce any notion of determinism but rather hints at an interactive, reflexive, and continuous process of socialization. A self, on the lines of G. H. Mead, constitutes itself in a representational process of synthesis of expectations and projections which anticipate the potential (re)actions of others and lead to reciprocal adjustments of behaviour. This reflexive "synthesis" of representations and counterrepresentations is continuously in need of renewal, of restructuration (the self in this process thus not being identical "with itself," as Sökefeld too remarks). The self is not a predetermined center of (inter)action but intersubjectively constituted in the continous process of developing its agency and making itself.

It should, then, be obvious that the different ways in which people in divergent cultural contexts relate to (concepts of) the self should not be lumped together under one heading, as if they would share the same distinctions from the streamlined "Western" concept of self. But there is a deeper ethnocentrism involved. Whereas the members of a culture which is said to lack a concept of self are supposed to be without selves, the concept of "culture" is, as Sökefeld remarks, imposed on others whether the culture has a concept of "culture" or not (this would not make it a nonculture). "Culture" is treated as a meta-term (of global differentiation) which seems unaffected by the critique of representation (although — or perhaps because - social actors the world over meanwhile have integrated this term, in particular ways, into their self-representations). Sökefeld, too, accepts "culture" as a "universal" and wants to give the same status to the "self."

It seems that Sökefeld confronts us with three principal options:

I. Follow this last suggestion and take culture, self, and perhaps other categories as universals-as fundamental interpretive frames. We would then have to navigate the waters of universalistic social theory, which with few exceptions takes its impulse from modern Western ideas, often already detached from any specific experiential context. The claims for universality and ontological primacy of these elementary categories can be doubted, as can any other universalistic schema, in epistemological as well as in political respects (as forms of a cultural hegemony). What one then might think of, at best, is a restrained, perspectivistic, and possibilistic universalism confronted by other positions with universalistic claims.

2. Remain on the conceptual level. "Self" or any other idea of personhood, individuality, or subjecthood one chooses to take would appear to be a culture-bound and relativistic notion and should be confronted with culture-specific ideas of "culture" or of inter- and transindividual linkages. The problem with this approach would not only be that it usually assumes a discreteness, or boundedness, of the entity concerned and a more or less homogeneous social whole but also that it favours concepts, expressly formulated ideas, and usually does not address social praxis-the question, in particular, of how ideas (of self, for example) are trans- lated into action, how they inform action, how they are dealt with in action (a problem on the agenda since the days of Max Weber). Assumptions about sociality, agency, interpretation, and their relationship, necessarily implied in any depiction of social processes, thus remain tacit. Many seem content to assume that a difference of concept makes a difference in social life, but to what extent and with what effect often remains unexplored.

3. Look for modalities of self and of collective identity (management) and culture (operation of symbols) "on the ground," on the "empirical" level, in social praxis. This would mean arguing for a "narrative ethnography of the particular," that is, the description of specific interactions and contextual conceptualizations and of individual or particular modes of negotiating one's way. Cultural meanings on this level are not necessarily discursively expressed but implicated in social praxis. It would therefore be imperative to elaborate on the analytical ground from which one operates-on the notions of actor, person, inter- and transsubjectivity, or signification employed. These must not be based on Western socio-philosophical traditions alone (see, e.g., attempts to theorize about cases of "complex agency" such as Strathern's [I990] suggestion of dyadic structures in contradistinction to collective actors for Melanesia). Some way or other the study of the particular would be linked to generalist but not necessarily universal prospects (unless one chooses to leave those generalities implicit or to the discretion of the text's readers).

Not only the first option but the others too present a dilemma. The only "solution" one can think of is to keep the issue in suspense, in a way which tries to reflect these difficulties and continously questions what seems established. That is, we cannot do without certain (analytical) assumptions of agency, person, intersubjectivity, symbolization, etc., and if we were to claim to do so we would only introduce them through the back door, as undiscussed notions. Especially, we cannot disregard the ethical implications of our categorial choices (which may or may not recognize the "others" and their claims). But that means that we have to keep in mind the tentative, provisional character of such theoretical assumptions, the fact that they are only suggestions-a specific intervention which remains open for critique, above all from other systems of knowledge. Any claim for universality would thus have to acknowledge its own specific contingency. And, secondly, concepts can be thought of as universal only insofar as they are underdetermined. That is, the moment one speaks of self or culture (or any other sociocultural "universal") one is already speaking of a specific, situated self or culture. There is no self or culture "as such," much less any general modality of self-culture-identity relationship. If self and culture are constitutively interlinked, as argued here, they cannot be juxtaposed in an abstract manner. Every-by definitionparticularized, situated ethnography has to keep in view the full polysemic character and ambivalence of a con- 
stellation, the countervailing tendencies, and the fact of unrealized possibilities latent in a situation (as for Sökefeld's example: Ali Hassan seems to be never fully present in a specific situation, never identical with himself or with the different sides to his "self"). This would also allow looking for ruptures and antagonisms in the relationship of selves to their inner and outer representations, discourses, or "identities" as well as ruptures and ambivalences within the self (the fact that the synthesization of the self does not always succeed). What Sökefeld calls "identities" can also be, in part, negative or imposed.

Sökefeld's stimulating paper points to the need for a comprehensive discussion of an interactive approach to culture, which, on the one hand, has to break up this unitary concept into its components, among them performative modes, discourses, social representations, schemata, and perhaps identities, and, on the other, to work out the different aspects of interaction, of linkage and interrelationship_-both their interpretive side and the constitutive intersubjectivity of subjects or selves.

DAVID N. GELLNER

Brunel University, Uxbridge, Middlesex UB8 3 PH, U.K. 22 III 99

There is much to reflect on in Sökefeld's ambitious and stimulating article. He takes us on a breathtaking gallop through recent philosophically inclined anthropology, as well as some older theoretical pieces, and concludes that anthropology would do well to give as much attention to selves as it does to culture.

He deliberately sidesteps discussions of the emergence of the Western conception of the person (Carrithers, Collins, and Lukes I985). This does, however, lead him to overlook the extent to which arguments such as that of Dumont (I980) are essentially juridical: what is absent from traditional India, supposedly, is the legally autonomous individual. Furthermore, Marriott can hardly be criticized for failing to specify what he thinks Indians have instead of this concept. Indeed, as has been perceptively pointed out by Parry (I994:II4), for the ethnographer trying to describe Indian selves the structuralist account of Dumont and the ethnosociological account of Marriott, far from being incompatible alternatives, actually imply each other: it is because Indians view themselves as permeable membranes, much as Marriott describes, that they need the rules about purity and pollution which Dumont sets out to analyse.

Sökefeld's central argument-that anthropology has tended to concentrate on identity in the sense of group or ethnic identity and has either left the discussion of personal identity to psychologists or assumed that group identity subsumed personal identity-is well made. It is surely true that anthropologists have too often presented individuals as illustrations of cultural patterns. Yet the exceptions to this are many. The very best ethnographies both describe in full the cultural and structural constraints that people face and present indi- vidual cases in enough depth for the reader to have a sense of how they make choices and cope with, struggle against, and sometimes turn to their advantage the situations in which they find themselves. From many possible examples, let me cite John Middleton's Lugbara Religion (I960), Lynn Bennett's Dangerous Wives and Sacred Sisters (1983), and Sherry Ortner's High Religion (I984), which is simultaneously a sophisticated theoretical statement about structure and agency.

The ethnography that Sökefeld presents is very suggestive and is meant to show that the ambiguities of social life are "not a threat but a great resource." He certainly demonstrates that society in Gilgit is highly complex, with numerous crosscutting and incommensurable "dimensions" of identity. The fact that social life in many places does indeed have this kind of complexity does not, however, mean that all choices are equally viable, that all actors have an equal ability to affect outcomes, or that there is not some kind of hierarchy of acceptability and viability among the various criteria of identity which may contextually be made use of. As Baumann (I996) has shown in an important recent analysis of Southall, a multiethnic West London suburb with a majority of Indian descent, the political context is central. In Southall (and much the same applies elsewhere) there is an official discourse which recognizes the existence of a fixed number of "communities" (for Southall, five), and there is a demotic discourse in which people recognize full well that there are all kinds of crosscutting links and forms of identity which undermine or negate the formally recognized communities. Yet the official discourse flourishes because it is the only way in which local politics can be carried on.

It is noticeable that politics and economics do not play a significant part in Sökefeld's analysis of his case study. He mentions the fact that Ali Hassan is a rich man whose patronage is desired, but this does not come up as significant later on. Nothing is said of the larger contexts of Pakistan or the Muslim world, though clearly the changes he refers to cannot be understood in isolation. In the framework Sökefeld has allowed himself there is no space to enlarge on such matters, but they may be unavoidable, as he recognizes towards the end of his argument when he begins to consider the question of power and the denial of personhood to others. This is of course something that has been of special concern to feminist anthropologists; a recent example is the essay by Des Chene (I998), which examines the fate of a daughter-in-law whose struggle with the constraints she faced was ultimately unsuccessful or successful only at great cost.

Thus my criticisms are essentially three (and are hardly disabling): (I) Sökefeld does not give credit to the many honourable exceptions to his strictures about an anthropology that ignores the self. (2) He could perhaps have made more of the point that a sense of self is bound up with a sense of worth and that this may vary with power. Could it be that the rich and powerful are particularly prone to be economistic calculating max- 
imizers, as Ali Hassan appears to be? In any case, there are well-known objections to the assumption that all individuals can be modelled as economists would wish. (3) Sökefeld's final sentence appears to go well beyond arguing that "selves" should be included as a "supplement" to culture and seems to suggest that they are essentially all there is. However, to say that culture "is only our [anthropologists'] construction" is to ignore the extent to which actors are constrained by it: Ali Hassan, despite his ingenuity, was constrained by the cultural definition of a wedding feast as one that contained meat and by his co-religionists' ban on sharing meat with Sunnis.

Despite these cavils, I fully agree with Sökefeld in his principal conclusion. Ethnographic writing should find a place for individuals and their actions; to exclude them or to insist that they are irrelevant is both methodologically disingenuous and theoretically flawed. I think it would be misguided to go beyond that, however, and suggest that person-centred ethnography is the only kind we want: it would be analogous to arguing that the only history worth writing is biography.

\section{BRIAN D. HALEY}

University of California Institute for Mexico and the United States, Universitywide Headquarters, Riverside, Calif. 9252I, U.S.A. (brian.haley@ucr.edu). I III 99

Sökefeld makes explicit a relationship between identity and self that, I think, many students of identity have been gravitating towards-some perhaps unwittinglyin recent years. His self as a manager of identities offers a possible answer to the question who or what is constructing or negotiating identities, inventing all those traditions, imagining so many communities, making ethnic choices, and experiencing hybridity. Fundamentally, Sökefeld's universal self suggests a locus of agency. Granted, many students of identity have been acknowledging the agency of individual actors for some time, giving me a small urge to quibble with Sökefeld's polarization of anthropologists' treatment of Western versus non-Western selves. But then, studying identity in California I do not confront an anthropological tradition of the sociocentric individual comparable to what Sökefeld faces working in South Asia. Indeed, the presence of this tradition gives him ample reason to provide us simultaneously with another useful critique of anthropological othering.

Sökefeld's premise is correct: anthropologists seldom explicitly place the individual within theoretical discussions of identity, choosing instead to view identity routinely as a shared group characteristic. In some general overviews of ethnic and national identity the individual or self goes virtually unmentioned. The few models describing the relationship between identity and self often cannot easily accommodate conflicting or crosscutting multiple identities that individuals must manage or the identity changes that people may em- brace late in life. A comparison with one especially durable and influential view of the relationship of self and identity (DeVos and Romanucci-Ross 1995: 366-69) illustrates some potential advantages of Sökefeld's model.

For DeVos and Romanucci-Ross, "a sense of identity is, by definition and by implication, a conscious part of the self." Ethnic identity, like a first language, is inseparable from a "personality structure [that] has rigidified into the consistent pattern of an adult." Individuals, thus, have only one "subjectively genuine" or "natural" ethnic identity, unless multiple identities are arranged in a hierarchical (segmentary?) order that precludes a "crisis in consistency" which could alter behavior and lead to a new identity. However, Ali Hassan's competing obligations and identities of religion, kin, and community coexist at the same level in practice and are equally "natural" to him. Difference arises not just in a transition to a new identity but as his multiple identities make competing claims and must be sorted out. Ali Hassan negotiates his way through this crisis and achieves much of his self-consistency through narrative after the fact. Models like DeVos and Romanucci-Ross's do not permit multiple "natural" identities of a single individual in a single setting, and perhaps they would not view each of Ali Hassan's various group identities as "ethnic" and thus equally addressed by their model. Sökefeld's self as manager of multiple and situationally conflicting identities elegantly does permit these sorts of phenomena that are problematic in other conceptualizations.

By escaping the trap of reified culture, Sökefeld allows for such patterns as traditions and identities invented or adopted later in life but experienced at some level as more "authentic" and "natural" than those they have replaced (Handler and Linnekin I984; see, e.g., Haley and Wilcoxon I 997). An encounter with différance might initiate the formulation of a new identity for the self to manage, one that can coexist with some old ways yet is also experienced sooner or later as "subjectively genuine." If we put a thinking self at the center of action, continuously renegotiating its position vis-à-vis new experiences of difference/différance through the socially constituting medium of identity, then we may puzzle less over how identities can change or exist in multiplicity or how "authenticity" itself changes. The degree of analytical distance between self and identity interjected by Sökefeld frees our thinking from the hegemony of "objective" culture inherent in DeVos and Romanucci-Ross's naturalness-culture's identity affiliation is always subject to reinvention anyway-without denying its influence.

I cannot pass up the chance to note the delicious irony of a potential human universal-nowadays often the concern of sociobiologists and evolutionary psychologists-operating according to a principle of différance defined by Derrida, that icon of deconstructionism. An intriguing aspect of Sökefeld's model is its potential to build a link between the more psychological- and evolution-oriented approaches (see, e.g., Levine 
and Campbell I972, Reynolds, Falger, and Vine i987) and the dominant sociocultural and constructivist ones. Might his redefinition of the relationship between identity and self suggest the necessary interdependency of nature and nurture? Is this a research area in which these two often seemingly irreconcilable approaches in anthropology can some day coexist in a mutually respectful and beneficial manner? Though my own work and biases lie on the sociocultural and constructivist side, I nurse a kernel of hope for that possibility.

JEANNETTE MAGEO

Department of Anthropology, Washington State

University, Pullman, Wash. 99164-49Io, U.S.A.

(jmageo@mail.wsu.edu). 24 II 99

Sökefeld argues that the selves of the people anthropology traditionally studies are defined by the negation of the Western self, that is, as lacking reflexivity and agency. This way of seeing others, furthermore, "actually denies them a self." There is a logical problem here. To talk about difference is not necessarily to talk reductively about people in other cultures.

I want to distinguish three types of difference: negative, gradated, and symmetrical. (I) Difference can be constructed like a photographic negative; then one sees others only in terms of what they are not. In Victorian culture, for example, women and non-Westerners were defined by a putative lack of certain qualities Western men had, most significant among them higher forms of reason (McClintock I995). (2) Difference can also be constructed as gradated; then one sees others as sharing certain qualities with oneself or one's own culture to a greater or lesser degree. Prior to the mid-I8th century, women were understood in Europe as exhibiting a gradated difference from men. ${ }^{1}$ Their genitals were named as inverted versions of male genitals, inverted because they had less of the vital heat necessary to push them out (Laqueur I990). (3) When one sees difference symmetrically, however, others are regarded as in many respects parallel yet distinct; people appear to be addressing similar problems and finding unique but comparable solutions. ${ }^{2}$

It is true that the anthropology of an earlier age sometimes assumed a negative or gradated stance towards selves in other cultures. Mead (I942), for example, calls the Balinese "schizophrenic" because they prefer acting a social role to expressing their inner thoughts and feelings. $^{3}$ Contemporary psychological anthropologists, however, are dedicated to a critique of negative and gradated constructions of cultural difference. Shweder and

I. Gradated differences are also exemplified by evolutionist perspectives on the colonial others (see Chatterjee r 993).

2. Latour (I993) argues for symmetrical explanatory principles in cultural analysis.

3. Mead's actual portrayal of the Balinese surpasses the judgments in which it is encased; many of her other works eschew the judgment of difference by a Western standard (see, for example, Mead I96I).
Levine's (r984) volume includes the work of many psychological anthropologists who critique psychologists' tendencies to make Western constructions of the person a universal standard. So do Lutz (I988) and Ewing (I990). Obeyesekere (I990) critiques the tendency of psychoanalysts to make Western understandings of consciousness and sanity a universal standard. Traces of prejudicial constructions of cultural difference are evident in this body of work, but none of these scholars see people in other cultures as lacking agency or reflectivity.

Why does Sökefeld misconstrue other scholars in this way? Because he identifies agency and reflexivity with the self as consistent, continuous, and distinct from others (a classic Western view) and not with the self as contextually cued "identities." As many psychological anthropologists attribute socially oriented, contextually cued identities to people in the societies they study, "it follows," Sökefeld asserts, that they deny agency and reflexivity to "the non-West." But why does he identify these quintessential aspects of selfhood with the self as distinct and continuous? Sökefeld shows that his Pakistani informant has multiple identities but, pulled this way and that by his life experiences, a distinct-continuous self that is not actively cultivated within his culture emerges and has to be reconciled with his contextualized identities. Sökefeld sees this emergence as a realization of reflexivity and agency and therefore equates the two, but there is another possibility.

I have argued (1995, I998) that the subjective dimensions of experience associated with individuality and the social dimensions associated with the form of selfhood that Sökefeld calls "identities" are present in people everywhere. In culture, one of these dimensions is to a degree linguistically and conceptually privileged and exists in dynamic tension with the other, less privileged dimension. People respond to this tension by producing a series of discourses on the self in which the more obscure dimension gradually emerges. This emergence is tantamount to a realization of agency and reflexivity, just as in Ali Hassan's case. My differences from Sökefeld are two. (I) Sökefeld sees discourse as unmarked by the exclusion of a disfavored dimension of experience. (2) I think Ali Hassan becomes increasingly agentic and reflexive through the emergence of a sense of self as distinct-continuous because this is a backgrounded dimension of experience in his society, not because agency and reflexivity are by-products of individuality in contradistinction to socially oriented forms of selfhood. In societies where a distinct-continuous sense of self is privileged, reflexivity and agency are actualized through the emergence of underprivileged social experiences, which brings with it a realization that distinct-continuous selfhood too is a cultural construction-that we are not really consistent but change from situation to situation, that we are effective only inasmuch as we act in concert with others, and so forth. This emergence is key for studies of the self, but we need a symmetrical explanatory principle to account for 
it, not one that valorizes a traditional Western model of the self.

MATTISON MINES

Department of Anthropology, University of

California, Santa Barbara, Calif. 93 I06, U.S.A.

(mines@sscf.ucsb.edu). I2 III 99

This article triggers such a broad host of reactions that it is hard to know where to start; let me begin, therefore, by stating what I find compelling in it. First, the individual and individuality need to be incorporated into analyses of society and culture if we are to advance our understanding of them and our relationship as individuals to them. Second, some sort of self is universal and is requisite to the thinking, planning, action-initiating individual (it is, as Michael Carrithers points out, also essential to human history). Sökefeld, then, is no Tolstoyan. Third (and to some extent I infer this), a sense of self is embedded in social relationships, which are affected by power differences, and requires constant management, weighing of circumstance and potential consequences of action, argument, and self-presentation. It is also a product of experience and reflection. Fourth, actions are influenced by culture and society; the individual is not an autonomous actor.

The way I read Sökefeld, therefore, is that he is arguing for anthropologists to change significantly the manner in which they do fieldwork, conceptualize society and culture, and analyze history: the key is an ethnography of the self and of identity. We must preserve the individuality of our informants-understand individual motivation and reasons for action and preserve how our informants engage in social relations, how they narrate their relationships to others, and how they make choices about how to act, thereby producing the processes of society, culture, and, I add, history. This article, then, is good stuff, full of ideas and, I believe, full of suggestions about how to turn anthropology's attention to the reality of tangible lives and actual people. This turns much 2oth-century anthropology, which has obscured or dismissed any social significance for the individual, experience, and motivation. There is much in this article, therefore, that is exciting.

There is, however, also much central to the article that is confused and indeterminate and must be addressed if anthropology is to reorient itself in the manner Sökefeld recommends. Most important, Sökefeld asserts that "the self should be taken as an universal like culture" and these two things should be understood as complementary. What does he mean? Certainly not much, if what he is saying is that as all societies have culture, all individuals have a self-culture and self being "understood in relation to one another." What, then, is this self he advocates? And what precisely is this relationship with culture? Further, the self is not the "same or essentially similar" for all people of the world-culture's effect, I presume-but selves are "not necessarily as different as many anthropological texts . . portray them." What does he mean by "culture," and precisely how is it a component of self? Earlier he writes that "agency, reflexivity, and the self go hand in hand." This further confuses me. Sökefeld seems to advocate a self that incorporates three levels of self-representation: "identities," emerging only after experience, out-of-context narratives that informants relate to an ethnographer about how they act and characterize themselves, and individual management of action and of narrative in "conflictual practical moments." What is the relationship among these levels?

I believe that what Sökefeld catches is that the self is a powerful locus for understanding action, motivation, and the everyday phenomena of social life. What I believe he misses, if ever so slightly, is that the self is first an awareness sustained in social relations. There can be no self-either in the West or elsewhere-that is autonomous. Such a sense is always an illusion. When his informants explain themselves to him, they do so by describing a kind of Bakhtinian dialogue with significant others. Indeed, much of self-awareness is brought into consciousness precisely because it takes the form of both internal and actual arguments with others about how to behave and how behavior should be estimated. Contrary to G. H. Mead, this self-consciousness allows his informants to examine their relationships, to imagine them configured in different ways and sometimes in new ways, and to attempt consciously to reconstitute relations and groups and so to transform society. All of the identities to which Sökefeld refers allude to groups constituted in this manner. This, then, is not just an after-the-act awareness but a planning, imagining, potentially creative awareness. Recognizing this puts the responsibility for social action and social history in human hands, which is where it belongs - in the hands of individual actors.

\section{NIGEL RAPPORT}

School of Philosophical and Anthropological Studies, University of St. Andrews, St. Andrews KYI6 9AL, Scotland, U.K. (njr2@st-andrews.ac.uk). 26 II 99

Sökefeld will appreciate that I am greatly in sympathy with the general ethos of his project. I might rehearse a number of its key themes as follows:

I. Anthropology après Durkheim has failed to recognize the significance of acting individuals ("selves"). This tendency has taken an extreme turn with the poststructuralist (Foucault, Jameson, Spivak, Gergen) negation of the identical subject.

2. More precisely, it has treated the conventional conceptualization of selfhood to the exclusion of its experiencing, as if there were no room for difference between them-between, let us say, "individualism" and "individuality."

3. Ruling out the significance of selves distinct from their socio-cultural conceptualization-regarding them 
as epiphenomenal, irrelevant, inaccessible, even nonexistent-has eventuated in facile dichotomies (Dumont: "the Western self may have become individualistic but the Rest remain sociocentric"), the hypostatization of "society" and "culture," and determinism.

4. A better approach is to investigate the socio-cultural as an object constructed by ongoing individual action, mediated by individual interpretation, and existent via experience which, while not free-floating, is individual both in provenance and in substance.

5. The individuality of experience translates, for example, into an individual's being able to develop a strong sense of self even in a setting which, conceptually, is non- or anti-individualistic.

6. The distance between the individual and the conventional conceptualization is especially apparent in situations of socio-cultural pluralism. Here it is impossible to account for the manoeuvring by individual actors among a diversity of public identities and their pursuit in different contexts of contradictory ends without reference to a self which selects courses of action and monitors their conditions, course, and outcome. The self offers the possibility of a stable point of reference from which to reflect on and manage a diversity of identities.

7. The stability of the experiencing self is acceded to via narrative. Telling themselves an ongoing story of self, individuals achieve a self-identity distinct from the images conventionally associated with the roles they play.

8. In this self-narrative the ambiguities surrounding different roles and the ambivalences about the distance between roles and self can become a cognitive resource: a means of considering new ways of structuring the social world and of acting within it.

9. In short, there can be neither human being nor becoming without selfhood, and individual agency vis-àvis the conventional is universal. Methodologically we must always attend to the self and retain an awareness of the individual amid the socio-culturally conceptual.

These themes accord, as I say, with conclusions of my own concerning the diversity of "worldviews" and "personae" which individuals can be seen to be responsible for and the agency evinced by individuals creating, maintaining, and realizing these in socio-cultural milieux (cf. Rapport I993). I would go farther than Sökefeld, however, in advocating a humanist-existentialist anthropology which recognizes the radical freedom or apartness of the individual: apart from so-called prior conditions, from seeming power inequalities, structures, and constraints, from others in a socio-cultural milieu, even from themselves.

First, it seems to me unnecessary to tie individuals' self-images to the plurality of relationship domains in which they are ensconced and not allow for self-images' being created ex nihilo. Secondly, I believe it is important to recognize that individuals may be inconsistent and self-contradictory but no less "themselves," no less agential, and no more the playthings of circumstance or discourse. (Sökefeld seems to say that inconsistency must be something of which individuals are conscious if it has practical, social consequences.) Thirdly, I find that the wrong status is being granted to the contexts and circumstances within which individuals live. (Sökefeld describes how individuals act in terms of problems set up by a long history of power relations and struggle.) In subscribing to his positions I feel that he is insufficiently open to the nature and effects of individual becoming.

If we say (after Redfield I960:59) that the "states of mind of particular people ... [their] complicated thinking and feeling ... is the real and ultimate raw material" of anthropology, since "it is there that events really happen," this is not a retreat into idealism but an accurate account of the irreducible dialectic between environments and their individual construal. The forms which individuals find around them (natural and sociocultural) achieve their continuing existence and significance by way of interactive-interpretive procedures conducted by individuals in the process of creating themselves. Worlds become and remain human by becoming individual, by way of individuals' interacting with them. It is an ontological error to describe Derridean forms (or Saussurean langues or Marxian conditions) as directly, causally, or meaningfully affecting the identities and worlds which individual interpretations give on to. Individuals carry with them their own experiential contexts, in short, and human social life is the story of a diversity of individual worlds abutting against one another.

\section{G ÜNTHER SCHLEE \\ Forschungsschwerpunkt Entwicklungssoziologie, Universität Bielefeld, Postfach IOOI3I, 3350 I \\ Bielefeld, Germany. 3 I 99}

Sökefeld addresses the classical problem of the social sciences: how to combine the social sphere (society, stucture, system ... I with what is going on with the individual actor. The easy way out of the problem has always been to ignore one of the two perspectives: to do either pure system theory (e.g., structural-functionalism, ecological determinism) or pure action theory, inspired by psychology or economics (e.g., rational choice, game theory). He is not as alone as he may believe in looking for a synthesis: In institutional economics and political economy one finds similar attempts. Social science has discovered that actual people do not completely fit the model of the Homo oeconomicus who calculates his costs and benefits and intelligently and freely pursues his self-interest at all times or that of the somewhat less impressive Homo sociologicus who is perfectly socialized and sheepishly obeys one set of role expectations after the other. Behind the variety of roles performed in the course of a day and behind the conflicting identities defined by different sets of criteria we 
find the continuous personhood of an actor who tries to remain plausible to himself/herself and others and strives for some sort of biographical consistency. Sökefeld criticizes a number of anthropologists for neglecting this "self." In my limited space I am not going to discuss whether this criticism is fully justified in all cases; those who are living can defend themselves.

Reading this paper, which is inspired by South Asian material, with the eyes of an Africanist, I find it surprising that Sökefeld almost reinvents Max Gluckman's theory of crosscutting ties, apparently without being aware of it, just as Gluckman (I955), in his turn, for some stretches of his way, inadvertently moves along paths trodden much earlier by Mauss (I969 [I93I]:I). Sökefeld develops his own terminology, which misses the established terms only narrowly ("intersecting"). For Gluckman, who starts from a rather Hobbesian perspective of ubiquitous conflict, the fact that peaceful integration is possible at all is due to the existence of crosscutting ties. They are the very cause of social "cohesion." We are limited in our conflicts with those who are by one set of criteria our adversaries by the everpresent possibility that they might be our allies by different criteria in the next conflict constellation. The awareness that what we do in one capacity can affect what we can do and what people do to us in another capacity can, of course, only be mediated by a "self" which exists continuously alongside the different roles it enacts. As this is applied to Western and non-Western examples alike, Gluckman's theory seems to be immune to the type of criticism levelled by Sökefeld against others.

Configurations of crosscutting ties of the type observed here in northern Pakistan occur frequently across Africa, also involving the presence of clans and other (self-styled) descent groups in more than one ethnic or linguistic grouping. This has been observed both in classical writings (Fortes I969:159) and more recently (Allen I994, Lamphear I976, Turton I994). For a long time these ties have been neglected because British and American anthropology have been mainly interested in analysing the internal systemic relationships of "societies" and "cultures" respectively as bounded units and, in the American case, in large-scale comparison of such units (Naroll I964). Everything which occurred between such units was underfocused as a consequence.

More recently it has been questioned whether such crosscutting ties always have the integrating and deescalating effect postulated by Gluckman's theory and found also in Sökefeld's examples. Hallpike (I977) for an area of New Guinea and Schlee (I997) for northern Kenya have described crosscutting ties that have conflict-escalating effects or open new rifts in the process of healing old ones. Under which conditions do they work in these different ways? There seems to be much more to crosscutting ties than those who once coined that concept imagined. Sökefeld's interesting material would be highly relevant in that theoretical framework, and he should be encouraged to address it more explicitly.

MARTIJN VAN BEEK

Department of Ethnography and Social Anthropology, University of Aarhus, Moesgaard, 8270 Hojbierg,

Denmark. IO III 99

Sökefeld offers a timely plea for more attention in anthropological analysis to "real" or "actual" individuals. His critique of the tendency in much scholarly work to treat individuals as mere carriers of particular cultural principles, forms, or concepts is in my opinion well-targeted, and his broad argument for "bringing the self back in" is welcome. Whereas the anthropology of the Karakoram-Hindu Kush region has produced classic studies of collective identity and ethnicity (e.g., Barth I969), Sökefeld's ethnographic work (see also Sökefeld I994, I997), shows clearly that here, too, people have multiple and crosscutting "identities." This offers a useful correction to the prevalent notion that such complexity and ambiguity are a product or consequence of (post-) modernity. Sökefeld suggests that we should take actual selves, acting people, as the starting point of our inquiries when we study "culture," and it is difficult to disagree. But does he himself take such a starting point? While I agree with him in many respects, I wonder whether his argument is not weakened by his reliance on "identity" as a central conceptual tool in his analysis.

When discussing the example of Ali Hassan, Sökefeld maintains that this must (?) be read as "management of identities," that he "enacted a number of identities," that he did so "strategically," and that this shows how people in Gilgit "pursued various and at times contradictory objectives." He asks, "How do they develop a sense of a continuous and consistent self in this context?" and answers that Ali Hassan is in his own opinion consistently "himself" and that he is "denying conscious efforts and strategies." Sökefeld resolves the problem by introducing a "narrative self" that "results in the creation of a personal image." But what is the status of this narrative self in relation to what "really" happened (i.e., the strategic management of identities)? It seems to me that while the concept may help us to understand how Ali Hassan can represent a consistent self (on pain of self-delusion?), it leaves the analysis of events through reference to reified conceptions of identity and community-multiple, but reified nonetheless-unchanged.

It seems to me that Sökefeld makes two problematic moves. First, the assumption that these events should be read as structured through the desire for a "coherent, consistent self" seems to me to be already informed by a particular reading that takes a singular conception of "identity" or self as its yardstick: coherent, unique, consistent. Events are seen through the lense of "identity," even though for Ali Hassan they appear to have 
to do with a complex of obligations, interests, family ties, and economic, political, and religious considerations, to name a few. The imposition of an "identity" framework obscures precisely what is interesting in the situation, namely, that personal readings (identifications?) of the situation and its demands inform the actions of the individual in question. How does "identity" help us to understand this complex of considerations?

Secondly, Sökefeld's resolution, through a narrative self, risks reinforcing the separation between researcher and people studied; they narrate, but the anthropologist knows what really lies behind: identities and their strategic management. In other words, it risks reintroducing the objectivist fantasy of anthropologists with perfect vision.

It seems to me that Sökefeld might extend the same agency-oriented perspective he applies to conceptions of the self to the concept of identity-or, rather, that he might consider, as Handler (I996) did, whether "identity" is at all a useful (cross-) cultural concept. Instead of "identity" I prefer to use "identification" to signal at once the practical, embodied social and political character of such relations, ideas, and practices. Among the advantages of this kind of conceptualization is that it opens up a field of interpretation that can in principle be shared by researchers and the people they study without a priori establishing a hierarchical relationship between "our" and "their" interpretations. There is, of course, a growing body of work on identity, community, and self that with varying degrees of success avoids the reifications that Sökefeld rightly deplores. Many of these approaches share a concern with language, rhetoric, and representation rather than with "identity" per se (e.g., Comaroff I996, Herzfeld I992, Roseberry I996). Such an approach does not preclude or diminish the need for the consideration of "actual individuals" that Sökefeld calls for.

Posing the issue as one of "identity" — the need for a coherent, stable self in a world characterized by multiplicity, contradicting and overlapping loyalties, demands, and obligations - risks turning humans into perpetually neurotic creatures grasping for an impossible wholeness. The ethnographic record, including Sökefeld's own work, shows that the negotiation of such complexities and contradictions is not destabilizing or even surprising to most people most of the time; in fact, it is the very substance of "culture." The problem of "identity," then, arises not necessarily from anxiety about one's "self" but from the insistence on singularity that is characteristic of semantic orders, which demand a purity that (social) reality cannot match. It is this insistence on purity, on singular identification, on wholeness, coherence, and consistency, which causes anxiety, precisely because its demand cannot "really" be met. Might not the "narrative self" which dissimulates a coherent, consistent self in the example of Ali Hassan reveal a defensive or justificatory strategy in the face of the demands of an insistent anthropologist rather than a self-oriented strategy for "identity"?
PNINA WERBNER

Department of Sociology and Social Anthropology, Keele University, Staffs. STs sBG, U.K. 22 III 99

Sökefeld raises important, long-neglected questions about the relation between self and identity and between plural or conflicting identities and agency or selfhood. His argument starts from present poststructuralist reflections about multiple identities, agency, and the subject which stress that identities exist in and through difference, by contrast to other identities. His timely call is to abandon earlier anthropological assumptions about an essential difference between Western and non-Western selves. But when he imputes to anthropology an "implicit parallelism of self and identity ... as something essentially shared" and singular, he is, I want to argue here, reflecting a broader tendency in the discipline towards anthropological amnesia.

Sökefeld asks, "What if the people anthropologists study cannot be categorized by shared identities? What if their identity is not one but, as in a plural society, a collection of differences setting them off from varying groups of others? ... if what is shared with some conflicts with what is shared with others?" We are led to believe that this is a question left entirely unexamined in the history of anthropology so far-indeed, a question arising from Derrida's notion of difference/différance or Avtar Brah's of subjective "intersections" of identities (of gender, race, class, sexuality). Once such contradictions and intersections are acknowledged, Sökefeld proposes, then individuals are necessarily disclosed phenomenologically to be empirical agents or acting selves even, as the rest of his paper reveals, when we know little about their self-consciousness, introspections, doubts, and ambivalences.

Against this I propose that the classic modern anthropological study of identity, The Nuer, published in I940, is a work which highlights not only that identities are constructed through difference (genealogical, segmentary) but that membership in different groups generates conflicts for individuals which can only be resolved situationally. Evans-Pritchard was still, however, working with a notion of multiple homologous identities on a rising scale. Identities, in other words, although conflicting and multiple, rather than intersecting nested in his analysis within one another according to a single principle of segmentation.

In Max Gluckman's reworking of The Nuer and in his model of crosscutting ties developed subsequently as a comparative theory, the move was to show the existence of endemic contradictions between principles of social organization in tribal societies and hence also between identities. The Manchester School conflict theory, as it came to be known, led to a consideration from the start, much as Sökefeld insightfully recognizes, of how conflicting identities impacted on personal agency and selfhood. In the Nuer instance, Gluckman pointed to the conflict between rules of exogamy and agnation, which meant that individual Nuer were subject to con- 
flicting loyalties (to affines, to agnates) impelling them to seek speedy resolutions to feuds. In the absence of such a resolution, men were prohibited from commensality or sexual relations with their wives and were quite often placed in mortal danger (Gluckman I955). But the theory was also applied to urban situations in town, a classic instance being that of the Kalela dance on the Zambian Copperbelt, in which dancers displayed a paradoxical mix of identities (Mitchell I956). Gluckman himself applied his theory to an analysis of the colour bar in South Africa in an attempt to understand why the endemic cleavages there did not explode into violent disorder (I94I, I955). Recently Robert Thornton has brilliantly extended this analysis to the political context of the new South Africa (I997).

Although not very explicitly developed, a theory of agency and the self was a by-product of the focus on organizational dialectics, on "the peace in the feud." The stress was often on ambivalence, internal conflict, and unresolved dilemmas without ever denying the integrity of the empirical agent or acting self buffeted like a tragic hero between social forces. This emphasis on ambivalence, prominent in postcolonial studies as well, is one which I find missing in Sökefeld's analysis. Thus Victor Turner (I957:330, emphasis added) sums up his analysis of Sandombo and other contesters for leadership among Ndembu: "In particular situations principles of organisation come into conflict within single groups. There are conflicts of loyalties, and there is therefore an anguished choice between goods, not between good and bad." Gluckman (I963:I 27) writes, "Every social system is a field of tension, full of ambivalences, of cooperation and contrasting struggle. This is true of relatively stationary-what I like to call repetitive-social systems as well as systems which are changing and developing." Thus headmen and chiefs, caught in "intercalary relations" between colonial administrators and kinsmen, were analysed as subject to "insoluble conflicts" (p. I54). In order to minimize these personal dilemmas-as well group conflictsactors employed strategies of "situational selection," a term which Gluckman and his students derived from Evans-Pritchard's analyses of Azande witchcraft along with the Nuer.

Ali Hassan, the protagonist in Sökefeld's account, caught between crosscutting loyalties to relatives and to co-religionists, plays a complex game replete with ambiguous and contradictory messages in his attempt to sustain all the different facets of his identity/personal network. Indeed, one wonders whether a hidden political agenda motivates him to bring along on a wedding visit a man, Sher Khan, known as a militant leader of the Shiite community and perceived to be beyond $q \bar{o} m$ relations. Whatever the wheels within wheels left unspoken, I would agree with Sökefeld that Ali Hassan is not to be described simply as a man with a fragmented self, lacking agency or a sense of subjectivity. Where I part company with him is in defining this subjectivity/selfhood as beyond culture.
There are powerful cultural moral ideas shaping Ali Hassan's choices and sense of selfhood as an integrated whole. Above all, he is a prominent local leader, a man of civic responsibility (Mines I994) and therefore a man of honour or izzat, an acting subject who is expected to display generosity, loyalty, and trust. In reading the case study, my sense is that Ali Hassan is driven to meet his social obligations even in the face of the dangers presented by the present troubles-which also generate a clash between conflicting interests and aspects of his multiple identities/subjectivity. Of course, there are many unscrupulous local leaders wishing to capitalize on the growing religious polarization generated by sectarian violence. In my own work I have tried to consider how small cadres of religious activists attempt to create unbridgeable cleavages by undermining the pragmatics of factional alliances, built upon transversal identities (Werbner I99I). The peace in the feud is here sustained by the likes of Ali Hassan with his powerful sense of personal honour-a complex but integrated cultural ethos, not a personal invention.

In sum, then, Sökefeld's contribution is to compel us to think once again about conflict, identity, and selfhood and to place these issues in the context of present poststructuralist debates. His critique of Occidentalist interpretations built on unfounded us-them contrasts is particularly apposite. Missing from his account, however, along with an erasure of an anthropological past is a more sustained analysis of the ambivalences generated by multiple loyalties and belongings and the holistic South Asian personal ethos that counteracts these fissiparous tendencies.

\section{Reply}

\section{MARTIN SÖKEFELD \\ Hamburg, Germany. 3 I v 99}

The central topic which my paper addresses concerns the relationship between the acting and reflecting individual and shared, nonindividualized frames of reference such as culture and identity within the anthropological enterprise. My intention is to balance some of the sociocentric bias of social/cultural anthropology. Although my presentation of that bias is polemically overdrawn-as I admit in the text-the critique involved can hardly be dismissed. However, I appreciate the reference of many commentators to the many writers who are aware of that bias and especially the reference by Werbner and Schlee to Max Gluckman's concept of crosscutting ties. Gluckman, however, focused on the social importance of these ties and much less on their meaning for the individual. Against the almost exclusive anthropological emphasis on the "cultural" I argue that the individual-as a reflexive center of awareness and agency-deserves more prominence than it is 
accorded in much anthropological analysis and representation. This is of course a very controversial field, and therefore the comments refer to a great number of issues, some of them related to far-reaching discussions. I can here address only some of them.

Attempting to systematize some of the critique, I discover first two broad directions of thought. One calls for taking my arguments still farther. Rapport makes the most radical move, allowing for "self-images' being created ex nihilo" and arguing that all the contexts and constraints of life are individualized in the process of becoming of the individual. Van Beek criticizes what he perceives to be my "imposition" of a (still reifying) framework of identity on the personal readings of complex situations. The other line of thought, however, aims at grounding individual selves in "political economy" (Driessen) or in the "constraints" of culture (Gellner). The challenge for me is to find a mediating position in which neither objectivity nor subjectivity is accorded primacy once and for all.

Of course self-images may be created out of nothing but imagination, but they may clash quite painfully with extraindividual conditions. Recognizing, however, that human beings are able and often willing to endure considerable pain for the sake of specific self-images, I prefer to see culture or structure not as a constraint but as a condition that facilitates certain self-representations without precluding others. However, our languages have difficulty in expressing nonhierarchical relationships, relations in which no single element is accorded the status of a cause and the other of an effect, and this formulation of "facilitating conditions" still gives primacy to the extraindividual. I try to conceive of the relationship between self and culture as "mutually causative." This is a banal proposition at a general level, for certainly there would be no culture without humans and no humans without culture, but at the level of the specific ethnographic case-and especially its ethnographic representation-it requires considerable reorientation. With its strong traditional emphasis on culture, conceived of as pre- and extraindividual, anthropology has a considerable inclination to put the individual on a secondary, derived and effected level. To convey the openness of culture, its condition of continually being "effected" by creatively acting individuals, it is necessary to highlight how individuals actually live with the conditions or rules of culture we easily represent as given. My argument is certainly not, as Gellner suggests, that "person-centred ethnography is the only kind we want" but that person-centered accounts, focusing not only on individual ideas and discourses but on practice, are a necessary balance for a discipline the central concept of which is culture.

It is in this context that I propose the "self" as a human universal like "culture," whether a specific culture contains a concept of self or not. With this I do not mean to offer another definition of human nature, but I am convinced that our descriptions of cultures are incomplete without accounts of how selves deal with or are involved in them. To take both concepts as universals is to restrict their pretensions. Fuchs, addressing the question of the universality of culture and self very lucidly, suggests that we have to keep the issue in constant "suspense" in our thinking and writing, and I agree with him. Therefore I have to admit that I cannot conceive of the precise general relationship between culture and self that Mines calls for apart from the very unspecific level to which I referred above. Given the specific conceptualization of self as outlined here, any concrete relation between culture and self is perhaps less an issue of our general conceptualization of both these "matters" than one of how specific selves conceive of and act toward what we call culture. Coming back to the question of the political economy of selfhood, this means that Ali Hassan's more independent standing was certainly facilitated by his relative prosperity and the respect he commanded (although, at the same time, the respect he commanded was also very much enhanced by this more independent, "nonsectarian" attitude). But certainly not everyone in Gilgit who was in a similar political and economic position acted in the same way, nor was everyone of lesser status necessarily more "sectarian-minded." Accordingly, I narrated the episode of the uneasy marriage visit less to illustrate a general relationship between self and culture and identity than to point out a range of possible relations by discussing an example which in my understanding contradicts much anthropological writing on identity. Further, I think that the issue cannot be posed as one of Homo economicus. The idea of the "economistic calculating maximizer" to which Gellner-correctly-quite critically refers falls short of capturing Ali Hassan's intentions. What is at stake in Ali Hassan's action is (personal) values, not simply economic maximization (and I contend that "economy" refers only to very simplified values). Ali Hassan had already decided that being a Homo socialis as far as possible, sustaining as many social ties as possible, was one of his highest values. Seen in terms of simply "economic" rational choice, a strategy of cutting ties with Sunnis and behaving simply as a leader of the Shia (a strategy that was quite common in Gilgit) might have brought more gains for Ali Hassan in terms of followers and leadership, but this was clearly out of question for him. He was choosing what seemed the most beneficial mode of action for himself within a framework set by his values.

Referring to Handler (I996), van Beek wonders whether identity is a useful cross-cultural concept at all and whether its employment does not risk an objectifying kind of representation that is better avoided. I concur with him and also with Driessen that we should restrict our employment of the concept to prevent it from becoming meaningless. But, apart from the question whether I employed the concept in such an objectifying manner, it has to be kept in mind that people in Gilgit (and elsewhere) in fact do use many objectifications referring to the identities of groups (in Gilgit, however, the term itself [or its Urdu equivalent] is not used with 
reference to groups like the religious communities or $q \bar{o} m$ about which I wrote here but only with reference to a political, "national" identity in contrast with Pakistan [see Sökefeld n.d. b]). They strongly insist on difference. Such objectifications, which are used mostly in discourse about identities but are contradicted by much interaction (see Sökefeld I997b), have to be accommodated by our conceptual framework. I propose the distinction between self and identity-allowing for a degree of analytical distance, as Haley writes - to allow this accommodation as individuals insisting on many kinds of differences are still able to move through them with great flexibility while retaining a sense of remaining the same. I do not want to speculate as to whether this sense of the self as continuous and consistent is a "need" and whether, consequently, individuals who are unable to maintain it become neurotics. Rather, I regard the maintenance of this consistency, presented in the narrative self, as an empirical matter and something that is "repaired" by the self if it is challenged by rupturing experiences or discourses. Of course, it was probably my insistent questioning which made Ali Hassan invent his hypothetical strategy of partaking in the wedding meal without eating meat, but I do not think that my insistence was so different from challenges voiced by people in Gilgit themselves. When challenged by his relatives in Napura and asked to stay, Ali Hassan also did not admit a conflict or rupture but preferred to keep silent. Further, I am not of the opinion that my interpretation of the case pretends to "perfect vision" (van Beek) on my part. Quite to the contrary, I am sure that I did not know better than Ali Hassan, for example, that his idea of partaking in the meal without taking meat was only hypothetical - after all, he did not do it. My understanding of the episode rather reveals social actors as quite competent social analysts-it is only that they mostly have to remain silent about their knowledge in order not to defeat its practical purpose.

I concur with Ewing that our levels of analysis are not the same. The specific importance of Ali Hassan's case for me is the possibility of comparing his self-representation with his practice in the context of his diverse identities and to see how in spite of the different pulls of his various social identities he is able to present a consistent self. I agree that such an analysis should if possible be extended to a less limited field, but there is the methodological difficulty of our discipline that the participant observation which is required to record actual practice cannot be organized like interviewing or clinical testing.

The case of Ali Hassan is of course simplified, as Driessen writes, because Ali Hassan's self has to deal with more identities than I reported-most notably with gender, which is probably socially the most effective and meaningful difference in Gilgit. Because many more identities are involved, I do not think that my interpretation applies only to societies of special complexity as Chaudhary remarks. I am convinced that everywhere selves have to deal with contradictions and a plurality of identities, whether they are derived from religion, "ethnic" identity, gender, class, political orientation, subcultural affiliation, or any other kind of difference.

Mageo and Driessen address the topic of conceptualizing difference. When I suggest allowing for more similarity in the conceptualization of others' selves, Driessen remarks that similarity and difference are closely bound together. This is true, but it is equally true - and I am by no means the first to state this - that anthropology has insisted much more on difference, both by its long-time predilection for the exotic and by its core concept of culture. Culture has, at least since Boas, been conceptualized as difference. It draws boundaries of difference around groups of people that are thereby distinguished as "a" culture from others. There has been little room for continuity across cultural boundaries (apart from "elements" borrowed or diffused), continuity which of course would call into question that very concept of culture. Only more recently has the question of cultural boundaries become an issue and continuity become part of an important reconceptualization of culture (see Ingold 1993). At the same time, however, the question of cultural difference has been drawn into innumerable political discourses which insist on difference and draw their respective political demands from that insistence. To allow for similarity is therefore a political issue too.

I appreciate Mageo's conceptualization of the coexistence in a society of different dimensions of subjectivity which are differently highlighted, and I agree with her that in psychological anthropology very important work has been done in overcoming negative and gradated constructions of cultural difference. The option of resorting to "symmetrical difference" in representations of others I regard with some reservation, however, recognizing that in the political economy of concepts Western concepts (however one-dimensional and reified they are, erasing so much of the difference that exists within what is considered "the West") still dominate the trade and set its standard. The question remains, however, whether a non-Western self exhibiting consistency and continuity has to be labeled as constructed according to the "Western model." I understand this as an insistence on difference not allowing for much similarity between "West" and "non-West," as it is implied that such a model cannot be a non-Western one. The intention of my text, however, is to question the colonization of attributes of selves such as consistency and continuity by "the West."

\section{References Cited}

\footnotetext{
A в U-LUGHOD, LILA. I99I. "Writing against culture," in Recapturing anthropology: Working in the present. Edited by Richard G. Fox, pp. I37-62. Santa Fe: School of American Research Press

ADLER, H. G., HERRMANN LANGBEIN, AND ELLA
} 
LINGENS-REINDER. Editors. I994. Auschwitz: Zeugnisse und Berichte. Hamburg: Europäische Verlagsanstalt.

AHMAD, MUMTAZ. I99I. "Islamic fundamentalism in South Asia: The Jamaat-i-Islami and the Tablighi Jamaat of South Asia," in Fundamentalisms observed. Edited by Martin E. Marty and R. Scott Appelby, pp. 457-530. Chicago: University of Chicago Press.

ALLEN, TIM. I994. "Ethnicity and tribalism on the SudanUganda border," in Ethnicity and conflict in the Horn of Africa. Edited by Katusyoshi Fukui and John Markakis, pp. I I 239. London: James Currey/Athens: Ohio University Press. [GS]

ARENDT, HANNAH. I958. The human condition. Chicago: University of Chicago Press.

B ARTH, FREDRIK. I969. Ethnic groups and boundaries. Boston: Little Brown. [Mv]

- I989. The analysis of culture in complex societies. Ethnos 54:1 $20-42$.

Press.

B A U MANN, G. I996. Contesting culture: Discourses of identity in multi-ethnic London. Cambridge: Cambridge University Press. [DNG]

Benedict, RUth. I949. Patterns of culture. New York: Mentor Books.

BENNETT, L. I983. Dangerous wives and sacred sisters: The social and symbolic roles of high-caste women in Nepal. New York: Columbia University Press. [DNG]

в OAS, FRANZ. I982. "Some problems of methodology in the social sciences," in Race, language, and culture, pp. 260-69. Chicago: University of Chicago Press.

B RAH, A VTAR. I996. Cartographies of diaspora: Contesting identities. London: Routledge.

CALHOUN, CRAIG. I994. "Social theory and the politics of identity," in Social theory and the politics of identity. Edited by Craig Calhoun, pp. 9-36. Oxford: Blackwell.

CARRIER, JAMES G. I992. Occidentalism: The world turned upside-down. American Ethnologist I9:I95-2 I 2.

-. I996a. "Introduction," in Occidentalism: Images of the West. Edited by James G. Carrier, pp. I-32. Oxford: Clarendon.

- I996b. "Maussian Occidentalism: Gift and commodity systems," in Occidentalism: Images of the West. Edited by James G. Carrier, pp. 85-I08. Oxford: Clarendon.

CARRITHERS, M., S. COLlins, AND S. LUKes. Editors. I985. The category of the person: Anthropology, philosophy, history. Cambridge: Cambridge University Press. [DNG]

CHATtERJEe, PARTHA. I993. The nation and its fragments. Princeton: Princeton University Press. [JM]

COHEN, ANTHONy P. I994. Self-consciousness: An alternative anthropology of identity. London: Routledge.

COMAROFF, J. I996. "Ethnicity, nationalism, and the politics of difference in an age of revolution," in The politics of difference: Ethnic premises in a world of power. Edited by E. N. Wilmsen and P. McAllister, pp. 162-83. Chicago: University of Chicago Press. [Mv]

CROSBY, CHRISTINA. I992. "Dealing with differences," in Feminists theorize the political. Edited by Judith W. Butler and Joan W. Scott, pp. I30-43. New York: Routledge.

DERRIDA, JACQUES. I982. Margins of philosophy. Chicago: University of Chicago Press.

DES CHENE, M. I998. "Fate, domestic authority, and women's wills," in Selves in time and place: Identities, experience, and history in Nepal. Edited by D. Skinner, A. Pach III, and D. Holland, pp. I9-50. Lanham: Rowman and Littlefield. [DNG]

DE VOS, GEORGE, AND LOLA ROMANUCCI-ROSS. I995. "Ethnic identity: A psychocultural perspective," in Ethnic identity: Creation, conflict, and accommodation, $3 \mathrm{~d}$ edition. Edited by L. Romanucci-Ross and G. DeVos, pp. 349-79. Walnut Creek: AltaMira Press. [BDH]

DUMONT, LOUIS. I965. The functional equivalent of the individual in caste society. Contributions to Indian Sociology 8: 85-99.

. I970. "The individual as an impediment to sociological comparison and Indian sociology," in Religion/politics and history in India: Collected papers on Indian sociology, pp. I3350. The Hague: Mouton.

. I980. Homo hierarchicus: The caste system and its implications. Chicago: University of Chicago Press.

ERIKS ON, ERIK. I980. Identity and life-cycle. New York: Norton.

EWING, KATHERINE P. I987. Clinical psychoanalysis as an ethnographic tool. Ethos I 5:I6-39. [KРE]

. I990. The illusion of wholeness: Culture, self, and the experience of inconsistency. Ethos I 8:25 I-78.

-. I99I. Can psychoanalytic theories explain the Pakistani Muslim woman? Intrapsychic autonomy and interpersonal engagement in the extended family. Ethos I9:I3 I-60. [KPE]

FARD O N, RICHARD. I990. "Localizing strategies: The regionalization of ethnographic accounts," in Localizing strategies: Re gional traditions of ethnographic writing. Edited by Richard Fardon, pp. I-35. Edinburgh: Scottish Academic Press.

FORTES, MEYER. I969. Kinship and the social order. London: Routledge and Kegan Paul. [GS]

FOX, RICHARD G. I985. Lions of the Punjab. Berkeley: University of California Press.

foucault, Michel. I979. Power, truth, strategy. Sydney: Feral Publications.

. I982. "The subject and power," in Michel Foucault: Beyond structuralism and hermeneutics, by Hubert Dreyfus and Paul Rabinow, pp. 208-26. Brighton: Harvester Press.

GEERTZ, CLIFFORD. I966. "Religion as a cultural system," in Anthropological approaches to religion. Edited by Michael Banton, pp. I-46. London: Tavistock.

. I973. "Person, time, and conduct in Bali," in The interpretation of cultures, pp. 360-4I I. New York: Basic Books. . I984. "From the native's point of view: On the nature of anthropological understanding," in Culture theory. Edited by Richard A. Shweder and Robert A. LeVine, pp. I23-36. Cambridge: Cambridge University Press.

GERGEN, KENNETH. I99I. The saturated self: Dilemmas of identity in contemporary life. New York: Basic Books.

- I994. Realities and relationships: Soundings in social construction. Cambridge: Harvard University Press.

GEWERTZ， DEBORAH，AND FREDERICK ERRINGTON. I99I. We think, therefore they are? On Occidentalizing the world. Anthropological Quarterly 64:80-91.

GIDDENS, ANTHONY. I984. The constitution of society: Outline of a theory of structuration. Cambridge: Polity Press.

GLUCKMAN, MAX. I940. Analysis of a social situation in modern Zululand. Rhodes-Livingstone Institute Papers 28.

. I955. Custom and conflict in Africa. Oxford: Basil Blackwell. [GS, PW]

. I963. Order and rebellion in tribal Africa. London: Cohen and West. [PW]

HALey, BRian D., AND Larry R. Wilcoxon. I997. Anthropology and the making of Chumash tradition. CURRENT ANTHROPOLOGY 38:76I-94. [BDH]

HALL, STUART. I990. "Cultural identity and diaspora," in Identity, community, culture, difference. Edited by Jonathan Rutherford, pp. 222-37. London: Lawrence and Wishart.

HALLOWELL, IRVING A. I955. "The self and its behavioral environment," in Culture and experience, pp. 75-I Io. Philadelphia: University of Pennsylvania Press.

HALLPIKE, C. R. I977. Bloodshed and vengeance in the Papuan mountains: The generation of conflict in Tauade society. London: Oxford University Press. [GS]

HANDLER, R. I996. "Is 'identity' a useful cross-cultural concept?" in Commemorations: The politics of national identity. Edited by J. R. Gillis, pp. 27-40. Princeton: Princeton University Press. [MV]

HANDLER, RICHARD, AND JOCELYN LINNEKIN. I984. Tradition, genuine or spurious. Journal of American Folklore 97: 273-90. [BDH]

HARRIS, GRACE GREDYS. I989. Concepts of individual, self, and person in description and analysis. American Anthropologist 9I:599-6I 2. 
HERZFELD, M. 99I2. The social production of indifference: Exploring the symbolic roots of Western bureaucracy. Chicago: University of Chicago Press. [Mv]

holland, DOROthy, AND ANDrew Kipnis. I994. Metaphors for embarrassment and stories of exposure: The not-soegocentric self in American culture. Ethos 22:3 I 6-42.

ING OLD, TIM. I99I. Becoming persons: Consciousness and sociality in human evolution. Cultural Dynamics 4:355-78.

- I993. "The art of translation in a continuous world," in Beyond boundaries: Understanding, translation, and anthropological discourse. Edited by Gisli Pálsson, pp. 2 Io-30. Oxford: Berg.

IAMES ON, FREDERIC. I984. Postmodernism, or, The cultural logic of late capitalism. New Left Review I 46:53-92.

JEN KIN S, RICHARD. I996. Social identity. London and New York: Routledge. [HD]

k r Oe ber, A. L. I917. The superorganic. American Anthropologist I9:I63-2 I3.

K UKLICK, HENRIKA. I99I. The savage within: The social history of British anthropology I885-I945. Cambridge: Cambridge University Press.

KUPER, LEO. I977. The pity of it all: Polarisation of racial and ethnic relations. Minneapolis: University of Minnesota Press.

LABOV, WILLIAM, AND DAVID FANSHEL. I977. Therapeutic discourse: Psychotherapy as conversation. New York: Academic Press. [KPE]

LA FONTAINE, JEAN S. I985. "Person and individual: Some anthropological reflections," in The category of the person. Edited by Michael Carrithers, Steve Collins, and Steven Lukes, pp. I23-40. Cambridge: Cambridge University Press.

LAMPHEAR, JOHN. I976. The traditional history of the Jie. Oxford: Oxford University Press. [Gs]

LA QUEUR, THOMAS. I990. Making sex. Cambridge: Harvard University Press. [JM]

LATOUR, BRUNO. I993. We have never been modern. Translated by Catherine Porter. New York: Harvester Wheatsheaf. [JM]

LAW, JOHN. I994. Organizing modernity. London: Blackwell.

LE VINE, ROBERT A. I984. "Properties of culture: An ethnographic view," in Culture theory. Edited by Richard A. Shweder and Robert A. LeVine, pp. 67-87. Cambridge: Cambridge University Press.

LE VINE, ROBERT A., AND DONALD T. CAMPBell. I 972 Ethnocentrism: Theories of conflict, ethnic attitudes, and group behavior. New York: John Wiley. [BDH]

LÉVY-BRUHL, LUCIEN. I963 (I927). L'ame primitive. Paris: Presses Universitaires de France.

LIFTON, ROBERT JAY. I993. The protean self: Human resilience in an age of fragmentation. New York: Basic Books.

LUtz, CATHERINe. I988. Unnatural emotions. Chicago: University of Chicago Press. [JM]

MC CLINTOCK, ANNE. I995. Imperial leather. New York: Routledge. [JM]

MC HUGH, ERNESTINE L. I989. Concepts of the person among the Gurungs of Nepal. American Ethnologist i 6:75-86.

MAGEO, JEANETTE MARIE. I 995 . The reconfiguring self. American Anthropologist 97:282-96.

- I998. Theorizing self in Samoa. Ann Arbor: University of Michigan Press. [JM]

MALINOWSKI, BRONISLAw. I922. Argonauts of the Western Pacific. London: Routledge.

MARRIOTT, MC KIM. I976. "Hindu transactions: Diversity without dualism," in Transaction and meaning. Edited by Bruce Kapferer, pp. I09-42. Philadelphia: Institute for the Study of Human Issues Press.

- I989. Constructing an Indian ethnosociology. Contributions to Indian Sociology, n.s., 23:I-39.

MARRIOTT, MC KIM, AND RONALD B. INDEN. I977. "Toward an ethnosociology of South Asian caste systems," in The new wind: Changing identities in South Asia. Edited by Kenneth David, pp. 227-38. The Hague: Mouton.

MAUSS, MARCEL. I969(I93I). "La cohésion sociales dans les so- ciétés polysegmentaires," in Essais de sociologie, pp. I33-47. Paris: Editions de Minuit. [Gs]

MEAD, MARGARET. I942. "Balinese character," in Balinese character, by Gregory Bateson and Margaret Mead, pp. I-48. New York: New York Academy of Sciences. [JM] - I96r. Coming of age in Samoa. New York: Morrow Quill. [JM]

MELUCCI, ALBERTO. I997. "Identity and difference in a globalized world," in Debating cultural hybridity: Multi-cultural identities and the politics of anti-racism. Edited by Pnina Werbner and Tariq Modood, pp. 58-69. London: Zed Books.

METCALF, BARBARA D. I989. Islamic revival in British India: Deoband, I860-I900. Karachi: Royal Book Company.

MIDDLETON, H. I960. Lugbara religion: Ritual and authority among an East African people. London: Oxford University Press for the International African Institute. [DNG]

MINES, MATTISON. I988. Conceptualizing the person: Hierarchical society and individual autonomy in India. American Anthropologist 90:568-79.

- I994. Public faces, private voices: Community and individuality in South India. Berkeley: University of California Press.

Mitchell, J. Clyde. I956. The Kalela dance. Rhodes-Livingstone Papers 27. [PW]

MORRIS, BRIAN. I978. Are there any individuals in India? A critique of Dumont's theory of the individual. Eastern Anthropologist 31:365-77.

. I994. Anthropology of the self: The individual in cultural perspective. London: Pluto Press.

MURRAY, D. W. I993. What is the Western concept of the self? On forgetting David Hume. Ethos 21:3-23.

NAROLL, RAOUL. I964. On ethnic unit classification. CURRENT ANTHROPOLOGY 5:283-3I2. [GS]

OBEYESEKERE, GANANATH. I990. The work of culture. Chicago: University of Chicago Press. [JM]

ORTNER, S. I984. High religion: A cultural and political history of Sherpa Buddhism. Princeton: Princeton University Press. [DNG]

OUROUSSOFF, ALEXANDRA. I993. Illusions of rationality: False premises of the liberal tradition. Man 28:28I-98.

PARRY, J. I994. Death in Banaras. Cambridge: Cambridge University Press. [DNG]

RADHAKRISHNAN, R. I987. Ethnic identity and post-structuralist differance. Cultural Critique 6:199-222.

RAP PORT, NIGEL. I993. Diverse world-views in an English village. Edinburgh: Edinburgh University Press. [NR]

. I997. Transcendent individual: Towards a literary and liberal anthropology. London: Routledge.

RATT ANSI, ALI. I994. " 'Western' racisms, ethnicities, and identities in a 'post-modern' frame," in Racism, modernity, and identity: On the Western front. Edited by Ali Rattansi and Sally Westwood, pp. I-86. London: Polity Press.

READ, K. E. I967. "Morality and the concept of the person among the Gahuku-Gama," in Myth and cosmos: Readings in mythology and symbolism. Edited by John Middleton, pp. I 85-229. Austin: University of Texas Press.

REDFIELD, ROBERT. I960. The little community and Peasant society and culture. Chicago: University of Chicago Press. [NR]

REYNOLDS, VerNon, VinCENT FALger, AND iAN Vine. Editors. I987. The sociobiology of ethnocentrism: Evolutionary dimensions of xenophobia, discrimination, racism, and nationalism. London and Sydney: Croom Helm. [BDH]

R O SEBERRY, W. I996. "Hegemony, power, and languages of contention," in The politics of difference: Ethnic premises in a world of power. Edited by E. N. Wilmsen and P. McAllister, pp. 7I-84. Chicago and London: University of Chicago Press. [MV]

ROSEnberg, Seymour. I997. "Multiplicity of selves," in Self and identity: Fundamental issues. Edited by D. Ashmore and Lee Jussim, pp. 23-45. New York: Oxford University Press. SAID, EDWARD W. I995(I978). Orientalism: Western conceptions of the Orient. Harmondsworth: Penguin. 
SCHLEE, GÜNTHER. I997. "Cross-cutting ties and interethnic conflict: The example of Gabbra Oromo and Rendille," in Ethiopia in broader perspective. Edited by Katsuyoshi Fukui, Eisei Kurimoto, and Masayoshi Shigeta, vol. 2, pp. 577-96. Kyoto: Shokado Book Sellers. [Gs]

SHWEDER, RICHARD A., AND E. J. BOURNE. I984. "Does the concept of the person vary cross-culturally?" in Culture theory. Edited by Richard A. Shweder and Robert A. LeVine, pp. I 5-99. Cambridge: Cambridge University Press.

SHWEDER, RICHARD A., AND ROBERT A. LE VINE. Editors. I984. Culture theory. Cambridge: Cambridge University Press. [JM]

SÖKEFELD, MARTIN. I994. Sin und Yeskun in Gilgit: Die Abgrenzung zwischen zwei Identitätsgruppen und das Problem ethnographischen Schreibens. Petermanns Geographische Mitteilungen I 38:357-69.

- I997a. Ein Labyrinth von Identitäten in Nordpakistan: Zwischen Landbesitz, Religion und Kashmir-Konflikt. Pakistan-German Research Project, Culture Area Karakorum, Scientific Studies 8. Köln: Rüdiger Köppe Verlag. [Mv]

_. I997b. "Discourse and action: Unequivocalness and ambivalence in identifications," in Perspectives on history and change in the Karakorum, Hindu Kush, and Himalaya. Edited by Irmtraud Stellrecht and Mathias Winiger, pp. IOI-I7. Köln: Köppe.

- I998. "'The people who really belong to Gilgit': Theoretical and ethnographic perspectives on identity and conflict," in Transformation of social and economic relationships in northern Pakistan. Edited by Irmtraud Stellrecht and Hans-Georg Bohle, pp. 95-224. Köln: Köppe.

. n.d. $a$ "On the concept 'ethnic group,"' in Karakorum-Hindukush-Himalaya: Dynamics of change. Edited by Irmtraud Stellrecht. Köln: Köppe.

. n.d.b. "Balawaristan and other imaginations: A nationalist discourse on the Northern Areas of Pakistan," in Ladakh: Culture, history, and development between Himalaya and Karakoram. Edited by M. van Beek, K. N. Bertelsen, and P. Pedersen. Aarhus: Aarhus University Press.

SPIRO, MELFORD. I993. Is the Western concept of the self "peculiar" within the context of world cultures? Ethos 21:107-53.
SPIVAK, GAYATRI CHAKRAVORTY. I988. "Subaltern studies: Deconstructing historiography," in Selected subaltern studies. Edited by Ranajit Guha and Gayatri Chakravorty Spivak, pp. 3-32. Oxford: Oxford University Press.

STEMLER, Józef. I94. "Stasio aus Krakau," in Auschwitz: Zeugnisse und Berichte. Edited by H. G. Adler, Herrmann Langbein, and Ella Lingens-Reiner, pp. I9-22. Hamburg: Europäische Verlagsanstalt.

STEPHEN, MICHELE. I995. A'isa's gifts: A study of magic and the self. Berkeley: University of California Press.

STEPHENSON, P. H. I989. Going to MacDonald's in Leiden: Reflections on the concept of self and society in the Netherlands. Ethos 17:226-47.

S T O LCKE, VERENA. I995. Talking culture: New boundaries, new rhetorics of exclusion in Europe. CURRENT ANTHROPOLOGY 36:I-I3.

STRATHERN, MARILYN. I990. The gender of the gift. Berkeley: University of California Press.

THORNTON, ROBERT. I997. "The potentials of boundaries in South Africa: Steps towards a theory of the social edge," in Postcolonial identities in Africa. Edited by Richard Werbner and Terence Ranger, pp. I36-6I. London: Zed Books.

TURNER, VICTOR. I957. Schism and continuity in the life of an African society. Manchester: Manchester University Press for the Rhodes-Livingstone Institute. [PW]

TURTON, DAVID. I994. "Mursi political identity and warfare: The survival of an idea," in Ethnicity and conflict in the Horn of Africa. Edited by Katsuyoshi Fukui and John Markakis, pp. I 5-3 I. London: James Currey/Athens: Ohio University Press. [GS]

VAIDYANATHAN, T. G. I989. Authority and identity in India. Daedalus i 8: 147-69.

WERBNER, PNINA. I99I. "Factionalism and violence in British Pakistani communal politics," in Economy and culture in Pakistan: Migrants and cities in a Muslim society. Edited by Hastings Donnan and Pnina Werbner, pp. I 88-2 I 5. [PW]

WICKER, HANS-RUDOLF. I997. "From complex culture to cultural complexity," in Debating cultural hybridity: Multi-cultural identities and the politics of anti-racism. Edited by Pnina Werbner and Tariq Modood, pp. 29-45. London: Zed Books.

\section{Errata}

Philip Carl Salzman writes that a reference cited in his reply to comments on his paper "Is Inequality Universal?" (CA 40:3 I-6I) was omitted from the list of references: Lewis, Herbert S. 1998. Righting wrongs or wronging Wright. Anthropology Today I4(2):2324.

For the report "The Zapotec-Imperialism Argument: Insights from the Oaxaca Coast," by Robert N. Zeitlin and Arthur A. Joyce (CA 40:383-92), the images for figures 3 and 4 were inadvertently transposed. The captions and figure numbers themselves match the text references.

A sentence was mistakenly omitted from Gayle Fritz's review of Balick and Cox's Plants, People, and Culture in the June issue (CA 40:402-3). It should have followed the first sentence of the next-to-last paragraph. With the missing (second) sentence included, that paragraph should begin as follows: "A more serious shortcoming, in my opinion, again stemming from decisions made by the publishing company, is the virtual absence of intext citations or footnote-style references. In addition, because the Suggested Reading list at the end of the book is incomplete, the reader is left at times unable to ascertain primary sources. Examples include a study of tattoos by Tricia Allen, mentioned on p. I23, a quote attributed to Charles Peters on p. I89, another quote, on pp. I92-93, by Harold E. Moore Jr., and still others on p. 197 (by D. Smith) and p. 200 (by Alison Wilson)." 
